\title{
Integrated pest management of Tuta absoluta: practical implementations across different world regions
}

Nicolas Desneux ${ }^{1}$, Peng Han,'Ramzi Mansour ${ }^{3}$, Judit Arno $^{4}$, Thierry Brévault ${ }^{5,6}$, Mateus R. Campos $^{1}$, Anais Chailleux ${ }^{6,7}$, Raul N. C. Guedes ${ }^{8}$, Javad Karimi ${ }^{9}$, Kouassi Arthur J. Konan ${ }^{1,10}$, Anne-violette Lavoir ${ }^{1}$, Mana G. Luna ${ }^{11,12}$, Meritxell Perez-Hedo ${ }^{13}$, Alberto Urbaneja ${ }^{13}$, François J. Verheggen ${ }^{14}$, Lucia Zappalà ${ }^{15}$, Khaled Abbes $^{16}$, Abid Ali ${ }^{17,18}$, Yunus Bayram ${ }^{19}$, Fernando Cantor $^{20}$, Andrew G. S. Cuthbertson ${ }^{21}$, Raf De Vis ${ }^{22}$, Fedai Erler ${ }^{23}$, Dnyaneshwar M. Firake ${ }^{24}$, Khalid Haddi ${ }^{25}$, M. Jamal Hajjar ${ }^{26}$, Khasan Ismoilov ${ }^{27,28,29}$, Coline C. Jaworski ${ }^{1,30,31}$, Marc Kenis ${ }^{32}$, Hao-tian $\mathrm{Liu}^{27,28,33}$, Hossein Madadi ${ }^{34}$, Thibaud Martin ${ }^{6,35}$, Ahmed Mazih $^{36}$, Gerben J. Messelink $^{37}$, Samira A. Mohamed ${ }^{38}$, Robert S. Nofemela ${ }^{39}$, Abiola Oke ${ }^{40}$, César Ramos ${ }^{41}$, Michele Ricupero ${ }^{15}$, Emmanouil Roditakis ${ }^{42}$, Pathour R. Shashank ${ }^{24}$, Fang-Hao Wan ${ }^{43}$, Ming-hui Wang $^{27,28,33}$, Su Wang ${ }^{31}$, Yi-Bo Zhang ${ }^{43}$, Antonio Biondi ${ }^{15}$

${ }^{1}$ Universite Cote Azur, INRAE, CNRS, UMR ISA, 06000 Nice, France

2 Yunnan Key Laboratory of Plant Reproductive Adaptation and Evolutionary Ecology, Laboratory of Ecology and Evolutionary Biology, School of Ecology and Environmental Sciences, Yunnan University, Kunming 650504, ChinalRTA, Cabrils, Spain

${ }^{3}$ ISEP-BG La Soukra, Section of Biological Sciences, University of Carthage, Tunis, Tunisia

${ }^{4}$ IRTA, Cabrils, Spain

${ }^{5}$ CIRAD, UPR, AIDA, Centre de recherche ISRA-IRD, Dakar, Senegal

${ }^{6}$ CIRAD AIDA HORTSYS, Univ Montpellier, Montpellier, France

${ }^{7}$ CIRAD, UPR, HortSys, Centre de recherche ISRA-IRD, Dakar, Senegal

${ }^{8}$ Departamento de Entomologia, Universidade Federal deViçosa, Viçosa, MG, Brazil

${ }^{9}$ Department of Plant Protection, Ferdowsi University of Mashhad, Mashhad, Iran

${ }^{10}$ Felix Houphouet Boigny University of Cocody, Abidjan, Côte d'Ivoire

${ }^{11}$ CEPAVE (CONICET-UNLP-CICPBA), Buenos Aires, Argentina

12 Universidad Nacional de San Antonio de Areco (UNSAdA), San Antonio de Areco, Argentina

${ }^{13}$ Centro de Proteccion Vegetal Y Biotecnologia, (IVIA), Instituto Valenciano de Investigaciones Agrarias (IVIA), CV-315, Km 10.7, 46113 Moncada, Valencia, Spain

${ }^{14}$ Gembloux Agro-Bio Tech, TERRA, University of Liege, Gembloux, Belgium

${ }^{15}$ Department of Agriculture, Food and Environment, University of Catania, Catania, Italy

${ }^{16}$ Department of Biological Sciences and Plant Protection, High Agronomic Institute of Chott-Mariem, University of Sousse, Sousse, Tunisia

17 Department of Entomology, University of Agriculture, Faisalabad 38040, Pakistan

${ }^{18}$ College of Life Science, Shenyang Normal University, Shenyang Liaoning 110034, China

19 Departments of Plant Health, Quarantine and Pest Management, General Directorate of Food and 
Control, Ankara, Turkey

20 Universidad Militar Nueva Granada, Bogotà, Colombia

21 Independent Science Advisor, York, UK

22 Proefstation Voor de Groenteteelt VZW, Sint-Katelijne-Waver, Belgium

${ }^{23}$ Akdeniz University, Faculty of Agriculture, Department of Plant Protection, 07070 Antalya, Turkey

24 Indian Council of Agricultural Research (ICAR), Pune - New Delhi, India

${ }^{25}$ Departamento de Entomologia, Universidade Federal de Lavras, Lavras, MG, Brazil

${ }^{26}$ College of Agriculture and Food Sciences, King Faisal University, Al-Hassa 31982, Saudi Arabia

27 State Key Laboratory of Desert and Oasis Ecology, Xinjiang Institute of Ecology and Geography, Chinese Academy of Sciences, Urumqi 830011, China

28 The Specimen Museum of Xinjiang Institute of Ecology and Geography, Chinese Academy of Sciences, Urumqi, China

${ }^{29}$ National Academy of Sciences of the Republic of Tajikistan, Dushanbe, Tajikistan

${ }^{30}$ Department of Zoology, University of Cambridge, Cambridge CB2 3EJ, UK

31 Institute of Plant and Environment Protection, Beijing Academy of Agricultural and Forestry Sciences, Beijing 100097, China

32 CABI, Delémont, Switzerland

33 University of the Chinese Academy of Sciences, Beijing 100049, China

${ }^{34}$ Department of Plant Protection, Faculty of Agriculture, Bu-Ali Sina University, Hamedan, Iran

${ }^{35}$ CIRAD HORTSYS, Univ FH Boigny, Abidjan, Côte d'Ivoire

36 Complexe Horticole d'AGADIR, Institut Agronomique et Vétérinaire Hassan II, 86150 Ait-Melloul AGADIR, Morocco

37 Wageningen University \& Research, Wageningen, The Netherlands

38 International Centre of Insect Physiology and Ecology, Nairobi, Kenya

${ }^{39}$ ARC-Plant Health and Protection, Pretoria, South Africa

40 National Horticultural Research Institute (NIHORT), Ibadan, Nigeria

41 OIRSA, Mexico City, Mexico

42 Institute of Agri-Food and Life Sciences, Hellenic Mediterranean University, Stavromenos PC, 71410 Heraklion, Crete, Greece

43 Institute of Plant Protection, Chinese Academy of Agricultural Sciences, Beijing, China

KEYWORDS: Invasive alien species; Chemical control; Biological control; Pheromone; Plant resistance; IPM

\section{ABSTRACT}

The South American tomato pinworm, Tuta absoluta (Meyrick) (Lepidoptera: Gelechiidae), has invaded most Afro-Eurasian countries and is threatening worldwide tomato production. Various strategies have been developed and implemented to manage this pest. Here, we present a timely review on the up-to-date development and practical implementation of integrated pest 
management (IPM) programs for tomato crops across different world regions infested by $T$. absoluta. While insecticide resistance is a growing concern, biological control via releasing or conserving arthropod natural enemies and sex pheromone-based biotechnical control are the most successful management practices. Agronomic control-related research is an emerging area where the soil fertilization and/or irrigation, as well as breeding of resistant cultivars, has the potential to enhance IPM effectiveness. Grower survey responses in the native areas (i.e., South America), early-invaded areas (i.e., first report between 2006 and 2012) and newly invaded areas (i.e., first report after 2012) showed that the control programs evolved along with the areas and time since invasion. Growers in the early-invaded areas shifted more rapidly from chemical control to biological control compared to those from the native area. In all concerned regions, the pest control failure risk following chemical insecticide applications and the high cost associated with either biological or biotechnical control methods have been the greatest concerns for growers. The information gathered from the native and/or early-invaded areas may help achieve a more effective management in newly invaded areas. Lastly, researchers are expected to break the bottlenecks of some key issues that would enable lowering application cost of novel biorational alternative management options.

\section{Key message}

Major advances of fundamental and applied research have been made on the management of Tuta absoluta.

Use of pheromones, biological control and agronomic and cultural control are important components of the implemented IPM programs.

IPM programs evolved along with the range and time after initial invasion and showed a decline in chemical control and an increase in non-chemical alternatives.

\section{Introduction}

Biological invasions are major components of global change, since they are increasingly challenging to modern agriculture due to the growing intensity of trade and human mobility (Simberloff et al. 2013; Paini et al. 2016; McNitt et al. 2019). Among invasive alien species, arthropod pests pose a significant threat to the stability of agricultural and natural ecosystems, and hence, the implementation of integrated pest management (IPM) programs is often required to decrease pest population densities (Desneux et al. 2010). IPM is a science-based decisionmaking process that enables sustainable control of insect pests while posing minimum harm to the environment (Kogan et al. 1998). It can be implemented by timely pest sampling/monitoring to estimate pest densities, being combined with judicious pesticide use and various "green" management methods including trapping and use of synthetic pheromones, biological control by conserving and/or releasing arthropod natural enemies, agronomic and cultural control through habitat manipulation and use of resistant crop varieties (Kogan 1998; Desneux et al. 2007; Meissle et al. 2011; Ragsdale et al. 2011). To some extent, the need of IPM programs for invasive arthropod pests is comparable and even greater than that for endemic ones (Witzgall et al. 2008; Ragsdale et al. 2011; Haye et al. 2016; Deligeorgidis et al. 2019; Moreau et al. 2019; Santoiemma et al. 2020; Shah et al. 2020; Gugliuzzo et al. 2021; Tait et al. 2021).

The South American tomato pinworm, Tuta absoluta (Meyrick) (Lepidoptera: Gelechiidae), 
recently reinstated as Phthorimaea absoluta Meyrick (Chang and Metz 2021), is a destructive pest on tomato crops. So far, $T$. absoluta has invaded more than 90 countries outside of South America (EPPO 2021), thus becoming a serious threat to tomato production worldwide and, to a lesser extent, a pest of other economically important solanaceous crops, including potato, eggplant, pepper and tobacco (Desneux et al. 2010, 2011; Campos et al. 2017; Mansour et al. 2018; Han et al. 2019a; Verheggen and Fontus 2019). Various biological and ecological characteristics of this species have contributed to its invasiveness and high feeding damage potential to solanaceous crops (Sylla et al. 2029; Campos et al. 2021a, 2021b; Ponti et al. 2021). These characteristics include the cryptic nature of larvae, high reproduction potential with multiple overlapping generations per year, strong dispersal capacity as well as moderate or high resistance to commonly used insecticides (Urbaneja et al. 2013; Biondi et al. 2018; Cherif et al. 2019a; Guedes et al. 2019). The spread of $T$. absoluta to new regions has led to significant yield losses, fruit quality reduction (Rostami et al. 2020), increased pest control costs (Desneux et al. 2011) and heavy reliance on chemical insecticides (Biondi et al. 2018). As a result, they have further disrupted local tomato IPM programs in these areas (Desneux et al. 2010; Han et al. 2018, 2019a; Mansour et al. 2019).

Progress in combining compatible preventive and curative pest control will make the implementation of IPM programs by growers and pest control researchers more cost-effective for managing invasive $T$. absoluta populations. In the past two decades, significant technological advances have been made in the areas of pest detection, pest surveillance, pest feeding damage assessment, and timely selection and application of management options. Despite the development of new pest control technologies, not all countries have the same economic access to them, even when stakeholders recognize their pest control utility. Therefore, the process of transferring the technology to recipient stakeholder communities should be mindful of local farming practices and other socioeconomic factors to promote higher user adoption and equitable access. In any case, sharing knowledge on the management techniques being used in each region is the first step for building regional collaborations. This effort could improve IPM programs in different regions and hence cross-border pest management success (Han et al. 2019a). We readily assume that a successful management of the pest in one country/region may largely lower the risk in the other neighboring ones. Therefore, we provide a comprehensive review on current advances in the IPM options and programs being used in the regions where this pest is distributed. In addition, we collected over 30 questionnaires data from the key researchers who had interviewed with local farmers, technicians and/or policy makers. These data allowed us to compare the components of IPM packages used in the native area (i.e., South America), early-invaded areas (i.e., Mediterranean basin, Europe, Northern and Eastern Africa, Middle East; 2006-2012) and newly invaded areas (e.g., sub-Saharan Africa, Central America, Asia; after 2012).

\section{Chemical control}

\section{Insecticide use and invasive species}

Insecticides are a major component of insect pest control in conventional agricultural systems. Starting in the 1960s, the use of insecticides in farming operations came under heavy scrutiny when their unintended effects in the ecosystem became widely recognized (Cooper and Dobson 2007; Aktar et al. 2009; Kohler and Triebskorn 2013; Guedes et al. 2016). Nevertheless, insecticides are routinely used for their key advantage of generating immediate, cost-effective 
pest reductions, especially when invasive species are the target pests, but effective pest control alternatives are lacking as it takes time to develop non-chemical control options (Lockwood et al. 2013; Liebhold et al. 2016; Guedes et al. 2019; McLaughlin and Dearden 2019). The rationale has also been applied to $T$. absoluta since chemical insecticide applications are the main control method to contain T. absoluta outbreaks (Guedes and Picanço 2012; Guedes and Siqueira 2012; Campos et al. 2017; Biondi et al. 2018; Mansour et al. 2018; Guedes et al. 2019; Rwomushana et al. 2019). Chemical control remains a dominant management tactic against $T$. absoluta, specifically in open-field tomatoes (Biondi et al. 2018). Young tomato seedlings with little leaf coverage favor $T$. absoluta early colonization, as the pest could attack stem buds with subsequent leaf-mining during canopy development and later fruit infestation. This pattern of attack not only affects the different plant parts throughout its development, but also allows the insect protection against insecticide spraying while hidden in these plant structures (i.e., stem bud, leaf, fruit) (Picanço et al. 1998; Guedes and Picanço 2012). Moth adults are mostly neglected in toxicological studies and are seldom considered a major target for chemical control (Biondi et al. 2015).

\section{Ever-changing patterns of insecticide use}

Chemical control of $T$. absoluta has had limited success, yet the reception of this pest in newly invaded areas is often characterized by a sharp rise in insecticide applications attempting to halt the spread of invasive populations and reduce impending yield losses (Guedes and Picanço 2012; Guedes and Siqueira 2012). For example, the 10-12 sprayings required for pest control prior to $T$. absoluta invasion in Brazil more than doubled reaching over 30 applications per tomato cultivation cycle at the onset of this species introduction (Guedes and Siqueira 2012). Such a heavy application harms the natural control by beneficial arthropods, which could otherwise be conserved when generally lower amounts of insecticides are applied (Nieves et al. 2015). A similar scenario was reported in Europe and North Africa (Desneux et al. 2011; Mansour et al. 2018), and it is also expected in early-invaded and newly invaded regions (Campos et al. 2017; Biondi et al. 2018; Han et al. 2019a).

Adjuvants of insecticide formulations, timing of insecticide applications and spraying technologies are important for improving chemical control of $T$. absoluta. For example, earlyseason prophylactic application of insecticides in combination with mineral oil well before vertical tutoring (otherwise known as trellising) of the plant has commenced is known to reduce the severity of $T$. absoluta infestations later in the season (Picanço et al. 1998; Guedes and Picanço 2012). Nonetheless, the control difficulties and the management consequences stemming from intensive insecticide use have led to insecticides being most frequently used against $T$. absoluta, as well documented in South America, the region of origin and early spread of this species. Organophosphates and pyrethroids were the early groups of insecticides used against the pest in South America, starting in the 1960s and extending up to the 1990s (Siqueira et al. 2000a; Lietti et al. 2005). The subsequent decline in organophosphate use in the region was followed by cartap, abamectin and intensified pyrethroid use (Siqueira et al. 2000a, 2000b, 2001). The late 1990 s and early 2000s were met with the use of the oxadiazine indoxacarb and a surge in use of chitin synthesis inhibitors (Silva et al. 2011; Gontijo et al. 2013), followed by the subsequent increase in popularity of the pyrrole chlorfenapyr, the spinosyns (particularly spinosad) and the diamides chlorantraniliprole and flubendiamide by the mid- 2000s (Silva et al. 2011, 2016; Gontijo et al. 2013). These latter four compounds remain in active use at present and, among these, spinosad is allowed in organic tomato production systems where azadirachtin and toxins 
of Bacillus thur- ingiensis (Berliner) (Bt) (Bacillaceae) serve as alternatives (Silva et al. 2011; Biondi et al. 2018).

The historical insecticide use pattern observed in South America for $T$. absoluta control has been seen also in other invaded regions for similar underlying reasons. The use of organophosphates and pyrethroids against $T$. absoluta in Europe took place early on after its introduction late 2006 in Spain (Desneux et al. 2010). As it further spread to coastal European and North African countries (Campos et al. 2017; Biondi et al. 2018), chemical control was soon followed by the use of indoxacarb, avermectins, spinosyns and more recently by the reliance on diamide insecticides (Haddi et al. 2012, 2017; Roditakis et al. 2018). Similarly, in Western Asian regions the initial chemical control approach for $T$. absoluta began with organophosphates and pyrethroids and subsequently transitioned to other pesticide chemistries, such as diamides, with azadirachtin and $B t$ toxins also playing a role in organic farming systems (Kader et al. 2017; Zibaee et al. 2018). The fast evolution of insecticide resistance among $T$. absoluta populations and associated control failures seems to be the key determinant in the observed changes in pattern of insecticide use.

\section{Insecticide resistance, control failure and other concerns}

Pest population genetic resistance is a common consequence of unbalanced insecticide use, which largely drives the pest control dynamics observed for $T$. absoluta worldwide (Guedes and Siqueira 2012; Biondi et al. 2018). This outcome was first recognized in South America, and then elsewhere (Biondi et al. 2018; Guedes et al. 2019), reaching nearly 60 instances of resistance to 24 insecticides worldwide as recorded in the Arthropod Pesticide Resistance Database (https://www.pesticideresistance.org) and a recent compilation (Guedes et al. 2019). Initial detection of insecticide resistance in $T$. absoluta populations from South America involved organophosphate and pyrethroid insecticides (Salazar and Araya 1997; Siqueira et al. 2000b; Salazar and Araya 2001; Lietti et al. 2005), apparently motivating the subsequent use of cartap and abamectin. Later, low to moderate levels of resistance to abamectin and cartap were also reported in Brazil (Siqueira et al. 2000b, 2001; Silva et al. 2016), where pyrethroid resistance receded (Silva et al. 2011). Detection of indoxacarb resistance soon followed in the region, but ranging only from low to moderate levels (Silva et al. 2011, 2016), while subsequent resistance to chitin synthesis inhibitors reached high levels by mid-2000s (Silva et al. 2011). Spinosad and diamide resistance was then detected in South America and seems to be expanding (Reyes et al. 2012; Campos et al. 2014, 2015; Silva et al. 2016).

The rapid development of insecticide resistance observed among $T$. absoluta populations in Europe and North Africa is directly linked to the insecticide resistance history of this pest in South America (Roditakis et al. 2015, 2017a, 2017b, 2018). The invasive strain of $T$. absoluta from South America (Central Chile) (Guillemaud et al. 2015) that was found in Spain in 2006 , was most likely already resistant to pyrethroids. This factor likely catalyzed the ensuing insecticide resistance problems with $T$. absoluta as it spread throughout Eurasia and Africa (Haddi et al. 2012). Thus, not only is the species invasion a matter of concern but also the genetics of the invading population or strain of T. absoluta (Guedes and Siqueira 2012; Biondi et al. 2018). Widespread resistance to organophosphates, pyrethroids and other compounds enhances the likelihood of the unwelcome introduction of insecticide resistant populations of $T$. absoluta to new areas. This emphasizes the importance of profiling this genetic process/phenomenon and recognizing its spread to new areas to allow its containment and mitigation. 
However, the failure of chemical control can also stem from improper application. This includes application that does not follow recommended guidelines for formulation preparation, use of adjuvants to improve insecticide efficacy, the level of plant coverage and application timing. Unfortunately, the risk of insecticide control failure due to improper field application is frequently overlooked and its occurrence is more likely to be misattributed to some characteristics of the target pest population. Nonetheless, the risk of insecticide control failure can be surveyed with some adjustments to the well-known bioassay procedures for detection and monitoring of insecticide resistance, that is, the use of realistic bioassay methods reflecting insecticide field exposure and standard endpoints tuned to the efficacy thresholds required for commercial field use of insecticides (Guedes 2017). This assessment on control failure likelihood has received increasing attention with $T$. absoluta, which was initially surveyed in Brazil, but is also taking place elsewhere (Silva et al. 2011, 2015; Gontijo et al. 2013; Roditakis et al. 2013).

Another important consideration on the topic of chemical control is the impact of insecticides on non-target species (Desneux et al. 2007). Some of the consequences of nontargeted insecticide exposure include (i) stress to non-target species including natural enemies and pollinators, among others; (ii) inadvertent selection for insecticide resistance on non-target species (again including natural enemies and other pest species); (iii) shifts in species pest dominance and status; and (iv) community stress (Barbosa et al. 2015; Guedes et al. 2016, 2017). These consequences were little studied in the context of $T$. absoluta control with insecticides. Considering that both the putative whitefly species and the tomato borer Neoleucinodes elegantalis (Gueneé) (Lepidoptera: Crambidae) may co-occur with $T$. absoluta, their presence can influence the host plant response to $T$. absoluta and determine different patterns of insecticide applications in the field. For instance, high whitefly infestation may minimize the incidence of $T$. absoluta, whiteflies becoming thus the primary target of insecticide use (Biondi et al. 2018; Guedes et al., 2019). For these reasons, further investigations on these topics are still required.

\section{Essential oil-based botanical insecticides}

As for other pest insects (Benelli et al. 2019; Pavela et al. 2020), the most developed botanical insecticides for $T$. absoluta so far are formulated with essential oils produced from botanical extracts (Soares et al. 2019). Several studies have examined the lethal and/or sublethal (e.g., on behavior) effects of essential oils derived from citrus peel (Campolo et al. 2017), cardamom (Chegini and Abbasipour 2017) and ajwain (Piri et al. 2020), which all demonstrated significant pest repellency and/or mortality efficacy. Growers are recommended to use those essential oil products alone and/or combined with other biorational options, such as arthropod predators and microbial pesticides (Mansour and Biondi 2021). However, several limitations, such as optimized and authorized formulations, for the practical inclusion of essential oils into IPM programs are still occurring (Pavela and Benelli 2016). Moreover, the compatibility of essential oils with effective biocontrol agents should be evaluated case by case (Biondi et al. 2012; Soares et al. 2019; Campolo et al. 2020). These reasons, together with cost, efficacy and reliability, may hamper the use of this control option by growers.

\section{Trapping and use of pheromones}

Sex pheromones are chemical cues released by an organism to attract conspecifics of the opposite sex for mating. In moths, males typically fly upwind toward attractant cues released by females (Cardé and Minks 1995). Due to their vital role in mediating insect mating behavior, the 
use of sex pheromones has been one of the focal points of pest control research, especially for moths of economic importance. The earliest, most widespread and successful application of sex pheromones is their use in detection and pest population monitoring. They were later used to control insect populations, through mass trapping and mating disruption (Witzgall et al. 2010). Like most lepidopteran species, the sex pheromone of $T$. absoluta consists of a blend of volatile molecules, evoking long-range male attraction as well as elicitation of a courtship behavior (Linn et al. 1987). Typically, female $T$. absoluta initiate the male calling behavior in the early morning with the release of a two-component sex pheromone consisting of a major component, (3E, $8 Z$, 11Z)-tetradecatrien-1-yl acetate (TDTA), found in $90 \%$ of calling females sex glands, and a minor component, (3E, 8Z)-tetradecadien-I-yl acetate (TDDA), accounting for the remaining $10 \%$ (Attygalle et al. 1996; Griepink et al. 1996; Svatos et al. 1996). Their synthesis has been improved, leading to higher yields and stereoselectivity (Puigmarti et al. 2015). These molecules are used in field monitoring efforts, mass trapping and mating disruption for $T$. absoluta (Caparros Megido et al. 2013).

\section{Monitoring}

The $T$. absoluta sex pheromone was used to increase the sensitivity of existing monitoring traps (both Delta traps and bucket traps), allowing earlier detection of small populations and rapid implementation of adequate management strategies (Benvenga et al. 2007). In an early field experiment, pheromone traps baited with $100^{\wedge} \mathrm{g}$ of TDTA were shown to catch on average 1200 males per trap per night, while less than a hundred of individuals were caught in the control (Ferrara et al. 2001). Under greenhouse conditions, catches were shown to increase linearly with pheromone release rates, until reaching a maximum number of captured individuals achieved with traps releasing $150{ }^{\wedge} \mathrm{g}$ of TDTA per day (Vacas et al. 2013). The pheromone release rate is affected by a variety of factors, including the pheromone packaging and the dispenser itself. The baseline release rates should be adjusted as needed for maximum pest control performance under different environmental conditions. For example, higher pheromone release doses are typically needed in openfield habitats exposed to desert climates (e.g., $3 \mathrm{mg}$ ) than under greenhouse conditions where the pheromone is not readily wind dissipated (e.g., 500 $\mu \mathrm{g}$ ) (Hassan and Al- Zaidi 2010). These pheromone quantities can be slightly lower by the addition of $5-10 \%$ of TDDA (Lobos et al. 2013). However, whether addition of TDDA increases trap efficiency and/or fidelity remains to be assessed. Because commercially produced pheromones (either containing both components or only the main pheromone component) attract non-target moths, survey programs should include a dissection-based identification of the trapped moth before initiating a management strategy (Roda et al. 2015).

During the last decade, a wide variety of trap designs have been field-tested, with dark-colored Delta traps being the most cost-effective and recommended design (Uchôa- Fernandes et al. 1994; Roda et al. 2015; Abd El-Ghany et al. 2016). These traps are typically made from paper or plastic into a triangular prism shape, left open at both ends, with placement of a sticky panel insert at the interior trap base and a pheromone lure suspended above the insert, but under the trap roof, for protection from the elements. Alternatively, water-filled bowls in combination with the pheromone lure can also be used for monitoring $T$. absoluta populations. Trap positioning with respect to vegetation (height, densities) influences the monitoring results (Ferrara et al. 2001), with traps located just above the plant height to be the most efficient. Definitive trap density guidelines have not been established and can vary by region and information source consulted (e.g., published literature, trap manufacturer). However, an initial reliable monitoring 
program can be achieved with 1 to 4 traps/ha (Mansour et al. 2019). Based on the number of males caught per pheromone trap, the risk of infestation can be evaluated and should be considered low for less than 3 individuals/week, moderate if between 4 and 30 individuals/week and high for more than 30 individuals/ week (Monserrat Delgado 2008).

\section{Mass trapping}

In general, mass trapping methods for reduction of $T$. absoluta population densities combine the use of lures, to attract one or both sexes, with large insect retention traps (Witzgall et al. 2010). Trap designs can include those described previously, i.e., Delta or water-filled bowl traps, or other modified versions (Lobos et al. 2013). Similar traps are sometimes used for monitoring and mass trapping, but water traps are usually preferred to Delta traps, which quickly saturate in case of high pest population densities. When the killing agent is a chemical (e.g., cypermethrin), this strategy is called lure-and-kill (Howse et al. 1998).

In addition to the lure that consists of a semiochemical blend, the mass trapping setup can include a light source to increase moth attraction (Hassan and Al-Zaidi 2010; Cocco et al. 2012; Castresana and Puhl 2017). Because the matefinding communication system of $T$. absoluta is guided by a female-produced sex pheromone, only males are caught in these traps, leading to a decrease in mating events and a reduction in crop damage (Jones 1998; Witzgall et al. 2010). However, the particular mating behavior and reproduction characteristics of $T$. absoluta represent challenges that counter the efficacy of mass trapping efforts. Tuta absoluta males are polygynic and mate on average 6.5 times (Silva 2008), and a large proportion of males must be trapped before a population can be controlled (Jones 1998; Witzgall et al. 2010). For the females, Caparros-Megido et al. (2012) demonstrated that they are able to lay viable eggs without mating with males (i.e., parthenogenesis) even though the rate is relatively low. The female also shows polyandry that greatly increases its reproductive outputs, and the benefits for the female are greater when copulates with multiple males (Lee et al. 2014). Interestingly, $T$. absoluta has recently been found to show polygyny (Wang et al. 2021), which may further undermine the effectiveness of mass trapping.

While pheromone-based monitoring involves only a limited number of traps per hectare, mass trapping requires placing a higher number of traps in various strategic positions in the crop field to remove a high proportion of male insects from the pest population. For example, in Tunisia, the recommended density of Delta or water traps is 32 or 36 traps ha $^{-1}$ for open-field mass trapping and 2 Delta or water traps for a $500 \mathrm{~m}^{2}$ greenhouse (Mansour et al. 2019). The doses of sex pheromone to be loaded on the diffuser are usually claimed to be similar to those used for monitoring efforts, even if some authors suggest adapting the pheromone dose to the level of infestation (Chermiti and Abbes 2012). Lobos et al. (2013) noticed that higher numbers of $T$. absoluta were captured near upwind borders of tomato fields suggesting that treatments should be concentrated near upwind parts of fields. Mass trapping is rarely sufficient to control $T$. absoluta populations and should be used in combination with other control measures to reach an acceptable level of crop protection (Cherif et al. 2018; Mansour and Biondi 2021).

\section{Mating disruption}

The mating disruption strategy aims to interfere with the mate-searching efficacy of males by saturating the environment with a synthetic female pheromone. Reductions in successful mating events lead to lower pest levels and minimal crop damage (Cocco et al. 2013; Caparros-Megido et al. 2013). The release of large amounts of sex pheromone is necessary to achieve significant 
results, with 500 to 1000 pheromone dispensers per hectare being deployed (Vacas et al. 2011; Cocco et al. 2013). But even by using $50 \mathrm{~g}$. ha ${ }^{-1}$ of sex pheromone, several factors can make this strategy inefficient to reduce the damage, including the pest population density, the migration of mated females to the treated area and the ability of female $T$. absoluta to reproduce par- thenogenetically (Michereff-Filho et al. 2000; Caparros- Megido et al. 2012). For this reason, studies on the application of the mating disruption strategy against $T$. absoluta in open fields and protected tomato crops showed mixed results (Michereff-Filho et al. 2000; Vacas et al. 2011; Cocco et al. 2013). In addition, the size of the areas treated could also affect the efficacy of mating disruption, and it is assumed to perform better in large farms than small plantings. Even if the efficiency of this method has been improved, its viability could be limited by the costs necessary for the production of pheromones and their field distribution.

\section{Biological control with microorganisms}

A great number of entomopathogens are lethal to $T$. absoluta including bacteria, fungi and nematodes. Microbial biopesticides are usually not as harmful to environment as chemical insecticides, tend to be safer for humans and other vertebrates and are compatible with other groups of beneficial organisms such as arthropod natural enemies (Gonzalez- Cabrera et al. 2011; Molla et al. 2011; Mansour and Biondi 2021).

\section{Bacteria}

Different subspecies of $B$. thuringiensis $(B t)$ including $B t$ kurstaki and $B t$ aizawai are used widely to manage lepidopteran pests on most vegetable crops. These groups are dominated microbial biopesticides as they are selective, safe and also affordable (Lacey 2016). The bacteria of this category produce cry toxins, which cause a specific mode of action. In the case of their efficiency, they are often comparable with chemicals in terms of the effect and other traits. During its sporulation phase, Bt naturally produce proteins, among them 8-endotoxins such as Cry and Cyt toxins, which have proven insecticidal properties on a variety of insect orders (Schnepf et al. 1998). Bt can also produce and secrete the vegetative insecticidal proteins (Vip) during the vegetative growth stage. Sellami et al. (2014) evaluated the toxicity of Bt Vip3Aa16 protein against $T$. absoluta. This toxin has higher potency than the $\delta$-endotoxins of $B t$ subsp. kurstaki Strain HD1. The commercial formulations based on $B t$ have been developed as a key component of the IPM strategy against $T$. absoluta. Earlier studies documenting the effects of Bt-based insecticides on T. absoluta were conducted in South America (Giustolin et al. 2001; Theoduloz et al. 2003), and additional complementary studies have been done in invaded areas. In Spain, Bt-based insecticides against T. absoluta have been assessed in laboratory, greenhouse and openfield conditions. They showed that Bt-based insecticides are highly efficient in controlling $T$. absoluta, with the first instar larvae being the most susceptible compared to the second and third instar larvae (Gonzalez-Cabrera et al. 2011). The suitable selection of $B t$ concentrations (e.g., $90.4 \mathrm{MIU} \mathrm{I}^{-1}$ ) together with desired subspecies of $B t$ including subsp. kurstaki or subsp. aizawai are able to reduce the pest density by more than $95 \%$. Spraying the same concentration of the product each week could achieve satisfactory management efficacy with lower cost (Urbaneja et al. 2012). Furthermore, Mollà et al. (2011) demonstrated that when Bt was used immediately after the initial detection of $T$. absoluta on plants, it did not interfere with the pest control efficacy of the commercial predator Nesidiocoris tenuis (Reuter) (Hemiptera: Miridae) when released because $T$. absoluta eggs were available. Consequently, the combined use of $B t$-based insecticides with the release or conservation of this 
predator forms a multi-stage integrated management for $T$. absoluta. In Northern Spain, another predator, Macrolophus pygmaeus (Rambur) (Hemiptera: Miridae), is often used in combination with Bt-based insecticides that are highly effective in controlling the first instar larvae of $T$. absoluta (Urbaneja et al. 2012).

\section{Entomopathogenic fungi}

The entomopathogenic fungus, Beauveria bassiana (Bals.) Vuill. (Ascomycota: Hypocreales) is a common microbial agent that causes mortality in a wide range of pest insects. This fungus exhibits epiphytic and endophytic activity against $T$. absoluta (Allegrucci et al. 2011; Klieber and Reineke 2016). The survey on the efficacy of a commercial mycoinsecticide based on $B$. bassiana against all instars of $T$. absoluta showed that the corrected mortality reached $30 \%$ to $50 \%$ (Klieber and Reineke 2016). The establishment of the fungus with endophytic behavior could overcome the shortcomings during conventional usage of fungal-based pesticides including poor persistence of the spores in the environment or high susceptibility to environmental stressors like UV radiation or rainfall (Vega 2018). In this case, one concern related to endophytic inoculation of the fungi is the corresponding metabolites, which might enter the food web. This concern should be considered during the registration process of the products and requires in-depth studies (Vega 2018). Nevertheless, entomopathogenic fungi like $B$. bassiana have various beneficial roles that have implications for managing $T$. absoluta infestations. This fungus has been shown to improve plant health by increasing uptake of water and plant nutrients, promoting root biomass and development via mycorrhiza-like and endophytic interactions because they induce systemic plant defense and antagonistic effects on phytopathogens (Dara 2019; Tall and Meyling 2018). Moreover, a liquid formulation based on strains of the fungus Metarhizium anisopliae (Ascomycota: Hypocreales) together with irrigation could cause high mortality to T. absoluta pupae (Contreras et al. 2014).

\section{Viruses}

Several granulovirus isolates from Phthorimaea operculella (Zeller) (Lepidoptera: Gellechiidae) (i.e., PhopGV) have been collected worldwide and evaluated in terms of insecticidal activity, which indicated differences depending on their geographical origin (Carpio et al. 2012; Vickers et al. 1991). Mascarin et al. (2010) demonstrated that a Brazilian PhopGV was able to infect $T$. absoluta, resulting in delayed larval growth and decreased pupation. Gomez Valderrama et al. (2017) reported the morphological characterization and classification of two Colombian granuloviruses: VG013, isolated from T. absoluta, and VG003, isolated from Tecia solanivora Povolny (Lepidoptera: Gelechiidae). This study showed that both viruses could kill $T$. absoluta larvae.

\section{Entomopathogenic nematodes}

Entomopathogenic nematodes (EPNs) are also able to infect the four instars of $T$. absoluta inside or outside leaf galleries in both laboratory and greenhouse experiments (Batalla-Car- rera et al. 2010; Turkoz and Kaskavalci 2016; Van Damme et al. 2016; Mutegi et al. 2017; Kamali et al. 2018). These studies indicated that both Heterorhabditis bacteriophora (Poinar) (Nematoda: Heterorhabditidae) and Steinernema carpocapsae (Weiser) (Rhabditida: Steinernematidae) have ideal potency to be used in foliar and soil applications for $T$. absoluta management programs in greenhouse tomatoes. Moreover, they are able to control other greenhouse pests including the greenhouse whitefly, Trialeurodes vaporariorum (West.) (Hemiptera: Aleyrodidae) and the western flower thrips, Frankliniella occidentalis (Pergande) (Thysanoptera: Thripidae) 
(Ebssa et al. 2004, Rezaei et al. 2015; but see Buitenhuis and Shipp 2005 for a low nematode infection in F. occidentalis). Nematode efficacy and its compatibility with other biological control agents or other agrochemicals promote its use within the IPM strategy. Nevertheless, the success of nematode use against $T$. absoluta will depend on cost, efficacy and reliability.

\section{Biological control with arthropods}

A variety of arthropod natural enemies have been explored to control T. absoluta. Overall, predators and parasitoids have received equal efforts for research and practical use. Much advances have been made on the use of resident biocontrol agents, whereas the selective importation of coevolved natural enemies from South America to invaded regions in the Eastern Hemisphere under the framework of classical biological control has been a rare occurrence. This outcome can be attributed to (i) the "first-strike advantage" of large research efforts concentrated on effective native natural enemies (e.g., the mirid predators and trichogrammatid parasitoids found in Europe) and (ii) the complicated procedures required by the legal framework of the Convention on Biological Diversity for accessing and sharing classical biological control agents (Balmford et al. 2010).

\section{Predators}

At least 60 species of generalist arthropod predators, belonging to 26 families have been detected preying upon $T$. absoluta. Of them, more than 50 species have been recorded in South America whereas ten, mainly hemipterans, have been reported in newly invaded European countries (Ferracini et al. 2019). Some of these species play an important role in the natural regulation of $T$. absoluta populations in its area of origin (Miranda et al. 1998; Picanço et al. 2011; Bacci et al. 2018). However, in the early-invaded areas, the importance of IPM programs based on the use of predators for $T$. absoluta control quickly became evident (Arno et al. 2009). Current field results indicate that the intentional use of commercially available predators for biological control of $T$. absoluta has only been successful in early-invaded areas of Southern Europe (Mollà et al. 2011; Calvo et al. 2012a; Oztemiz et al. 2012; Urbaneja et al. 2012; Arno et al. 2018a; Biondi et al. 2018). It is still too early to determine if similar predator-based biological control practices are having a significant impact in other areas recently invaded by $T$. absoluta (Shaltiel-Harpaz et al. 2016; Varshney and Ballal 2017; Ismoilov et al. 2020; Mansour and Biondi 2021). Nevertheless, the two commercially available predatory mirid bugs, $N$. tenuis and $M$. pygmaeus, have emerged as key biological control agents for T. absoluta in Europe (PérezHedo et al. 2021a). The success obtained with the use of mirids in European tomatoes has prompted other geographical regions, mainly in the American continent, to study the pest control application of native mirids (Pérez-Hedo et al. 2021b; Roda et al. 2020). The effectiveness of mirid predators such as $N$. tenuis and $M$. pygmaeus can be attributed to i) their voracious consumption of T. absoluta eggs (Arno et al. 2009; Urbaneja et al. 2009; Sylla et al 2016) and ii) their zoo- phytophagous feeding habit, which allows them to subsist on tomato plants during periods of prey scarcity (Thomine et al. 2020; Pérez-Hedo et al. 2021a). Field data collected during the last 10 years shows that early mirid establishment is crucial for control of $T$. absoluta. Effective control of $T$. absoluta is very difficult if mirids are released when the pest is already established on the crop (Urbaneja et al. 2012). Therefore, mirids should be conserved or released augmentatively in nurseries during transplanting and preplanting activities. Due to the diverse climatic conditions in which the tomato is produced and the zoophytophagy of these biocontrol agents, the use of mirid bugs for $T$. absoluta control may require insecticide 
treatments under certain circumstances to either complement the action of the predators or prevent crop damage due to their feeding. In this case, the selection of the insecticide has to be done carefully to fulfill the desired goal (Arno and Gabarra 2011; Gonzalez- Cabrera et al. 2011; Mollâ et al. 2011; Zappalà et al. 2012; Urbaneja et al. 2013).

\section{Predatory mirid bug inoculation after transplanting}

A common practice for biological control of greenhouse tomato pests in Europe, particularly for whiteflies, is the inoculative release of $N$. tenuis and $M$. pygmaeus at a rate of 1-2 individual(s) $/ \mathrm{m}^{2}$, occurring 3-4 weeks after transplantation (Gabarra et al. 2006; Calvo et al. 2009). This strategy can also be effective for managing $T$. absoluta during short crop cycles when transplantation begins at the end of winter and the crop season can last until summer (Molla et al. 2009). Under these growing conditions, mirids are released when T. absoluta pressure is low; hence, it is possible that mirids may establish their populations before the populations of $T$. absoluta increase. During this crop cycle, temperatures increase with time which favors both the predators and the pest. If $T$. absoluta increases faster than the predator populations, the predator-prey balance could be prey-biased. As a consequence, treatments as selective as possible on mirid bugs will be needed (e.g., Bt-based insecticide). This scenario is more frequent when the control relies on $M$. pyg- maeus because it is less voracious than $N$. tenuis (Molla et al. 2009; Pérez-Hedo et al. 2015). A different situation occurs when N. tenuis is released and the predator could build up high populations at the time the crop is still growing. In this case, even if a successful control of the pest is achieved, the predator may damage the crop due to its phytophagy (Castané et al. 2011; Pérez-Hedo and Urbaneja 2016). Therefore, insecticide sprays to reduce $N$. tenuis populations have to be recommended, although the complete elimination of the predator is not advisable.

\section{Predatory mirid bug inoculation before transplanting}

In the nursery, adult mirid predators are released at a rate of 0.5-1 individual per seedling-plant and initially fed with eggs of Ephestia kuehniella (Zeller) (Lepidoptera: Pyrali- dae) (but see Messelink et al. 2014: food sprays with Artemia cysts (brine shrimp eggs) will be less costly than E. kuehniella). The eggs laid by mirids hatch very soon after transplanting, allowing a very early and homogeneous predator establishment on the crop. This augmentative biological control strategy was first implemented at the end of the 1990s to facilitate the establishment of $M$. pygmaeus for Bemisia tabaci (Gennadius) control on commercial tomato (Lenfant et al. 2000) and its application was later extended to the use of $N$. tenuis for controlling $T$. absoluta (Calvo et al. 2012a, b). This extension proved to be highly successful in long-cycle tomato production systems that start under medium-high pest levels in late summer, most notably in greenhouse systems in Almeria, Spain (Calvo et al. 2012b). Under these long-cycle production systems, released $N$. tenuis establish rapidly and provide effective control of both $B$. tabaci and $T$. absoluta until the arrival of winter when predator and pest levels naturally decrease due to lower temperatures. Rarely $N$. tenuis populations reach densities that are damaging to the crop during winter. However, in certain years with very mild winters, insecticide sprays are needed to reduce predator populations and prevent crop feeding damage. The following spring, $N$. tenuis levels rise again shortly before the end of the crop growing cycle, when the risk of crop damage is much lower. Nevertheless, if the overwintering populations of $N$. tenuis have not recovered properly, preventive insecticide applications may be needed to suppress $T$. absoluta. In these cases, complementary management strategies such as egg parasitoid releases (Chailleux et al. 2013a; Gabarra et al. 2014), use of pheromones for mass trapping and/or sexual disruption 
(Caparros-Megido et al. 2013) and conservation of native parasitoids (Zappalà et al. 2013; Gabarra et al. 2014), may be needed for T. absoluta control.

\section{Predatory mirid bug conservation}

For several decades, conservation of predatory mirids has been a key component of tomato IPM programs in the Mediterranean region (Albajes and Alomar 1999; Bompard et al. 2013; Arno et al. 2018a). This biological control option has proved to be successful in controlling this invasive pest in Europe (Arno et al. 2009; Jaworski et al. 2015). It is worth mentioning that the role of natural habitats and landscapes surrounding tomato cultivation in the colonization of tomato crops by mirid predators has been widely recognized (Alomar et al. 2002; Castané et al. 2004; Gabarra et al. 2004; Aviron et al. 2016; Ardanuy et al. 2018; Agustf et al. 2020). In this context, the use of ecological infrastructures (e.g., flower margins) with plants such as Calendula officinallis L. (Asteraceae) could maintain the occurrence of M. pygmaeus populations in the proximity of tomato crops. This strategy has been successfully adopted in Northeast Spain and Southeast France to increase population densities and the earliness of predators colonizing the crop (Lambion 2011, 2014; Balzan 2017; Ardanuy et al. 2018). However, implementing conservation biological control has promoted not only $M$. pygmaeus but also $N$. tenuis. Importantly, cultivation of Sesamum indicum (L.) (Pedaliaceae) as companion plant has been suggested as a promising strategy for reducing plant damage caused by $N$. tenuis on tomato (Biondi et al. 2016; Naselli et al. 2016). The provision of sugar dispensers on tomato plants could also limit plant damage by diminishing mirid phytophagy (Urbaneja-Bernat et al. 2018). In addition, promoting particular indirect interactions among various pests in a single crop could enhance biocontrol services provided by generalist predators (van Veen et al. 2006; Desneux \& O'Neil 2008; Desneux et al. 2019). Recent works demonstrated that such indirect interactions could occur between $T$. absoluta and other pests inhabiting tomato crops when mirid predators are released (e.g., M. pygmaeus, Bompard et al. 2013; Jaworski et al. 2015; Han et al. 2020), and that these interactions may be used as levers for optimizing IPM programs (Chailleux et al. 2014a).

\section{Parasitoids}

Close to 100 species of hymenopteran parasitoids belonging to Chalcidoidea, Chrysidoidea and Ichneumonoidea, have been recorded in association with $T$. absoluta throughout the world, primarily in South America. Among them, only three parasitoid species, Neochrysocharis formosa (Westwood), Trichogramma dendrolimi (Matsumura) and Trichogramma exiguum (Girault), were recorded in association with $T$. absoluta in both native and recently invaded areas (Ferracini et al. 2019). Interestingly, a strong pattern of natural enemy adaptation has emerged in invaded ranges of the Eastern Hemisphere, with 53 parasitoid species forming new host associations with $T$. absoluta over the last decade (Salas Gervassio et al. 2019a). However, only a few promising species have been considered for the development of biological control strategies, including conservation, augmentative and classical biological control options (Desneux et al. 2010; Biondi et al. 2013; 2018; Gabarra et al. 2014; Biondi et al. 2018; Salas Gervassio et al. 2019a).

\section{Egg parasitoids}

Currently, only egg parasitoids belonging to the family Trichogrammatidae have been used for $T$. absoluta control. Trichogrammatids can parasitize eggs from at least eight insect orders and some species have been used successfully in large-scale biological control programs targeting 
lepi- dopteran pests (Huang et al. 2020; Qu et al. 2020; Cherif et al. 2021; Zang et al. 2021). In South America, at least eight trichogrammatid species are commercially available for biological control of $T$. absoluta, but their field use is still limited. The biology, ecology and taxonomy of the Neotropical species Trichogramma pretiosum (Riley) have been well studied, and a commercial strain is available in Brazil, Chile, Colombia, Ecuador and Peru. The use of T. pretiosum, alone or in combination with $B t$ formulations, has proven successful for control of $T$. absoluta in Brazil (Parra and Zucchi 2004; Medeiros et al. 2009). Indeed, integration with chemical control is only possible by using reduced-risk pesticides (Gonzalez 2003). Use of Trichogramma nerudai (Pintureau \& Gerding) and Trichogrammatoidea bactrae (Nagaraja) was also evaluated. Field releases of $T$. nerudai in greenhouse tomatoes were carried out in Corrientes province, Argentina, and proved to be effective in reducing $T$. absoluta population densities (Tezze and Botto 2004; Virgala and Botto 2010). Currently, this species is commercialized in Chile. The species $T$. bactrae is mass-reared and released in Chile and Peru to control T. absoluta. Other Trichogramma species such as T. galloi (Zucchi) in Brazil; and T. pintoi (Voegele), T. exiguum (Girault), T. fuentesi (Torre) and T. cacoeciae (Marchal) in Peru are available from commercial insectaries in South America. The species $T$. bactrae and T. cacoeciae are under study in earlyinvaded regions by $T$. absoluta, such as Northern Africa.

Among egg parasitoids of $T$. absoluta used in Europe, high parasitism rates (> $90 \%$ ) were reached under greenhouse conditions following releases of Trichogramma achaeae (Nagaraja and Nagarkatti), both alone and in combination with the mirid predator $N$. tenuis (Cabello et al. 2009, 2015; Oliveira et al. 2017). Similarly, a slightly higher T. absoluta control level was achieved by combining the release of $T$. achaeae with the mirid M. pygmaeus (Chail- leux et al. 2013b). Thus, the parasitoid $T$. achaeae has been commercialized as $T$. absoluta biocontrol agent in Europe and Northern Africa. By running a laboratory screening of 29 European strains of Trichogramma parasitoids against $T$. absoluta (Chailleux et al. 2012), one strain of Telenomus euproctidis (Girault) appeared promising compared to $T$. achaeae, because $T$. euproctidis shows a higher parasitism rate, higher fertility, higher proportion of females and higher capacity of entering in diapause under cold storage conditions in biocontrol company facilities. However, it did not perform efficiently under greenhouse conditions (Chailleux et al. 2012). The combination of several variables, such as the rearing system (plant and host egg) and temperatures (during development and use) could strongly influence the efficiency of these biological control agents, in terms of longevity and fertility (Cascone et al. 2015).

In Africa, augmentative biological control of $T$. absoluta using native Trichogramma egg parasitoids has only been implemented in a couple of North African countries, i.e., Tunisia and Egypt (Mansour and Biondi 2021). Release of $T$. cacoeciae and Trichogramma bourarachae (Pintureau \& Babault) significantly reduced $T$. absoluta densities and plant damage either in protected or open-field tomatoes in Tunisia (Zouba and Mahjoubi 2010; Zouba et al. 2013; Cherif et al. 2019b). Moreover, several strategies have proved to be useful in Egypt: (i) releases of either the indigenous $T$. euproctidis or the cosmopolitan $T$. achaeae (50 or 75 parasitoids $/ \mathrm{m}^{2}$ ) (ii) $B t$ var. kurstaki application combined with releases of Trichogramma evanescens (Westwood) (70-75 adults $/ \mathrm{m}^{2}$ ) and mass trapping, (iii) releases of $T$. achaeae combined with releases of the predator Macrolophus caliginosus (Wagner) (Hemiptera: Miridae) and application of Bt, (iv) releases of $T$. bactrae in combination with mass trapping or $(\mathrm{V})$ releases of $T$. evanescens at seedling stage, significantly reduced insect densities and crop damage in northern Egyptian open-field and greenhouse tomato crops (Khidr et al. 2013; El-Arnaouty et al. 2014; Kortam et al. 2014; Goda et al. 2015; Rizk 2016). As far as we know, the practical use of parasitoids for 
managing $T$. absoluta in sub-Saharan Africa has not been documented.

In Asia, use of trichogrammatid parasitoids for control of $T$. absoluta has only been attempted in Turkey, Iran and Saudi Arabia (Mansour and Biondi 2021). Combined releases of the parasitoid $T$. evanescens and the predatory mirid $N$. tenuis proved to reduce fruit infestation in greenhouse tomatoes in the western Mediterranean region of Turkey (Keçeci and Oztop 2017). Similarly, releases of Trichogramma embryophagum (Hartig) parasitoids (20 adults per plant) along with $B t$ application or release of Trichogramma brassicae (Bezdenko), combined with spinosad spraying, significantly decreased $T$. absoluta densities and leaf mines in Iranian greenhouse tomato crops (Alsaedi et al. 2017; Jamshidnia et al. 2018).

\section{Larval parasitoids}

Among known larval parasitoids of $T$. absoluta, only Dolichogenidea (= Apanteles) gelechiidivoris (Marsh), Pseudapanteles dignus (Muesebeck) (Hymenoptera: Braconidae), Dineulophus phthorimaeae (de Santis) and Necremnus tutae (Ribes and Bernardo) (Hymenoptera: Eulophidae) have been considered as part of IPM programs in South America and Europe (Salas Gervassio et al. 2019a, 2019b). Currently, the utility of these parasitoids is restricted to conservation biological control programs. One species, $D$. gelechiidivoris sourced from Peru, is being studied to develop a classical biological control program for T. absoluta in sub-Saharan Africa (Aigbedion-Atalor et al. 2020).

In Chile, the importance of naturally occurring parasitism levels was recognized by Larrain (1987) who recommended avoiding early insecticide sprays to conserve existing field populations of $D$. phthorimaeae and $D$. gelechiidivoris. In the 1980s, in Colombia, Agudelo and Kaimowitz (1997) reported levels of larval parasitism up to $70 \%$ and the implementation of an IPM technology based on the conservation of Apanteles spp., releases of the Trichogramma spp. and treatments with Bt. The level of adoption and pest control success of this program is uncertain; however, its use decreased with time and ended up being minimal. More recently, Morales et al. (2014) evaluated the effectiveness of the parasitoid D. gelechiidivoris alone or together with sex pheromone traps and obtained better results with the combination of both strategies. Despite all these efforts, Herrera Rocha et al. (2018) reported that chemical control is widely used in Colombia and indicates that biological control will only be possible if combined with selective pesticides.

In Argentina, spontaneously occurring larval parasitism in commercial fields is mainly caused by $P$. dignus (Sanchez et al. 2009; Salas Gervassio et al. 2016), although it is found coexisting with the parasitoid $D$. phthorimaeae on the same host (Luna et al. 2010). Several studies revealed important levels of parasitism up to $75 \%$ in non-sprayed fields and up to $26 \%$ in crops with frequent insecticide applications (Sanchez et al. 2009; Luna et al. 2010; Nieves et al. 2015). This undoubtedly contributes to the natural biological control of the pest. Preliminary releases of $P$. dignus done in experimental tomato crops were not very successful (Folcia 2013). Further experimental work conducted by Salas Ger- vassio (2017) on P. dignus in greenhouse tomatoes provided promising results for pest control.

In Europe and the Mediterranean Basin, the situation does not differ much. Among the indigenous parasitoids associated with $T$. absoluta, only a few are considered as potential biocontrol agents (Zappalà et al. 2013; Gabarra et al. 2014). Necremnus tutae (Ribes \& Bernardo), first identified as N. nr. artynes (Walker) (Chailleux et al. 2014b; Gebiola et al. 2015), is the only species that was mass-reared in biofactories, although currently it is not commercially 
available. Since biological control of the pest in this region is massively relied on the use of predatory mirid bugs from the very beginning (Urbaneja et al. 2012), the combined use of both the predator and the parasitoid was examined (Calvo et al. 2016). This latter study showed that releases of the parasitoid were not necessary to control $T$. absoluta after pre-planting application of the predatory bug $N$. tenuis. However, the role of parasitoids in conservation biological control is recognized in Tunisia (Abbes et al., 2014) and in Spain (Arno et al. 2018b). In fact, an IPM program based on the conservation of $N$. tutae together with releases of $N$. tenuis and $T$. achaeae and the use of mating disruption is currently being recommended in Southeast Spain (Crisol and van der Blom 2018).

\section{Agronomic and cultural control}

Agronomic practices via manipulation of fertilization and irrigation have the potential for achieving $T$. absoluta control through bottom-up effects (Han et al. 2019b). For instance, lower nitrogen $(\mathrm{N})$ input resulted in lower performance of $T$. absoluta in tomato plants via bottom-up forces (Han et al. 2014; 2016), but did not disrupt the efficiency of biocontrol agents (Han et al. 2015a, 2015b; Dong et al. 2018). These findings were encouraging for reaching the goal of IPM; however, they were obtained from manipulative microcosm and/or mesocosm experiments, which may not translate into population effects at larger-scales, e.g., greenhouses. If we carry out inundative releases of biocontrol agents (e.g., M. pygmaeus and/or $N$. tutae) for controlling $T$. absoluta under greenhouse conditions, it is important to monitor the population growth of $T$. absoluta when the crops are treated with varying levels of nitrogen fertilizers. Reduced $\mathrm{N}$ fertilizer may impede tomato growth, but it may also help reduce the damage by $T$. absoluta, which could jointly affect tomato yield and quality. Moreover, applying less $\mathrm{N}$ fertilizer to crops has the potential to secure and even boost crop yields when applied in an appropriate way, while posing limited environmental damage (Chen et al. 2014). There is a tradeoff in this issue, and it is important to figure out how much $\mathrm{N}$ fertilizer could result in a multi-beneficial situation, i.e., lower fertilizer input, enhanced pest control and increased yields. This agronomic practice could be applied both for greenhouse and open-field tomatoes.

Adoption of resistant cultivars is another option that could be implemented in IPM programs against $T$. absoluta. A novel tomato cultivar has the potential to confer resistance to $T$. absoluta (Snoeren et al. 2017), but its performance in greenhouses and/or fields has not been assessed. In addition, insecticidal hybrid SN19 gene- and Cry1Ac gene-mediated resistance have been successfully developed in potato and tomato, respectively (Ahmed et al. 2017; Selale et al. 2017). So far, however, no tomato cultivar has been commercially available for targeting $T$. absoluta. The rapid development and robust risk assessment of those resistant cultivars are necessary before they could be adopted by growers in large areas. Notably, breeding of novel insect-resistant cultivars expressing long dsRNA that target pest essential genes in plastids (Zhang et al. 2015; 2017), being highly speciesspecific and thus environment-safe, could be a promising component of the IPM package against $T$. absoluta.

For both greenhouse and open-field tomatoes, routine surveillance and removal of infested leaves from young seedlings in the early season reduce the initial population size of the moth, which could considerably lower the risk of population eruption during the season. Though laborintensive, these practices are the most straightforward, thus lowering the follow-up of management inputs. For greenhouse tomatoes, several options could minimize the crop infestation by $T$. absoluta. First, physical barriers such as compartment exclusion by fine mesh and the design of double doors in the entry into greenhouses could be helpful to reduce 
infestation risk (Desneux et al. 2010; Biondi et al. 2018). Second, removal of alternative host plants inside/around the greenhouses could help suppress $T$. absoluta population. However, this practice requires growers to identify the wild plant species that may act as potential seasonal bridge hosts (Arno et al. 2019). Efforts are thus needed to update the list of alternative host plant species and train growers to target these plants for removal in each region (e.g., Ciceoi and Gutue 2020). Third, crop rotation shifting from tomato to other non-solanaceous crops (e.g., leafy vegetables) could break the life cycle of $T$. absoluta, thus limiting the population build-up. Last but not the least, exposing the greenhouse fields to ambient temperature in winter, notably in certain regions with a cold winter, can kill a large proportion of remaining pest individuals that attempted to overwinter in the shelter (Li et al. 2020).

\section{Developed IPM programs}

A standardized questionnaire form was designed and disseminated to the researchers from nearly 30 countries who work on $T$. absoluta management (see Supplementary Materials). The form includes choice questions where scores are requested, and open questions where detailed answers are requested. The contacted researchers responded to a questionnaire by gathering knowledge on the importance/diffusion of each IPM strategy (i.e., warning and early diagnosis, cultural, biotechnical, biological and chemical control) for managing $T$. absoluta, in three main tomato-producing areas during three main periods: (i) before 2006 (only for the native area), i.e., before the first record of the pest outside its area of origin; (ii) 2006-2012 (for native and earlyinvaded areas), i.e., the Mediterranean region and Central Europe invasion period; (iii) after 2012 (for the three areas: native, early-invaded and newly invaded areas), i.e., the subSaharan Africa, Asia and Central America invasion period. Further practical information on the current needs of the tomato industry for a suitable control of $T$. absoluta was gathered as well. For contacted researchers, information has been provided after interviewing local farmers, technicians, policy makers and by reading outreach and scientific documents in each concerned country. Four questionnaires for three countries in the native area (Brazil, Argentina and Colombia), 13 questionnaires for the early-invaded area (12 countries) and 17 questionnaires for the newly invaded area (14 countries) have been obtained. For each questionnaire, an overall score of $100 \%$ was divided among the five $T$. absoluta control approaches according to their importance in a given area during a given period. The average values of these percentages are presented in Fig. 1. One limitation of our study is that the questionnaire survey does not allow us to obtain estimated costs associated with each control tools in different areas.

\section{Tuta absoluta IPM temporal and geographical evolution}

Tuta absoluta is currently considered a major concern in almost all tomato-producing areas around the world (Supplementary Materials: Tables S1, S2 and S3). Applying synthetic chemical pesticides has been the most adopted IPM management tool by farmers to cope with $T$. absoluta infestations in tomatoes, regardless of the area or the period (Fig. 1). This management approach has mainly involved several in-season sprays of broad-spectrum active substances belonging to various insecticide chemical sub-groups including indoxacarb (oxadiazines), chlorantraniliprole (diamides), emamectin benzoate and abamectin (avermectins), deltame- thrin (pyrethroids) and spinosad (spinosyns) (Tables S1, S2 and S3). However, it is worth mentioning that there has been a remarkable reduction of chemical pesticide input for managing $T$. absoluta in all concerned tomato-producing areas worldwide, and especially, this has been the case in the early-invaded area as compared to the native area (Fig. 1). Furthermore, the reduction in 
chemical insecticide use in the native area (South America) started to become more evident after the year 2006, with no significant reduction in insecticide use until recently. This fact provides evidence that chemical insecticides are a necessity for South American farmers for controlling $T$. absoluta, and apparently, they do not rely on pesticide-free, more expensive alternative biorational control options.

Although not commonly used in native and newly invaded areas, the biological control with arthropod natural enemies through releases of Trichogramma spp. egg parasitoids and/ or the predatory mirid bugs $N$. tenuis or $M$. pygmaeus or by applying the microbial pesticide $B t$ has been of great interest in early-invaded area, i.e., Europe and the Middle East and North Africa region since the year 2012 (Fig. 1, Tables S1, S2 and S3). Importantly, as shown in Fig. 1, the main goal of using biological control in early-invaded countries has been to reduce the overuse, and in some cases, the misuse of hazardous chemical pesticides that have proved to generate detrimental side effects on non-target arthropods, human health and the environment, in addition to the resistance to pesticides in $T$. absoluta populations. In this context, major concerns have been rising in all geographical areas about the occurrence of resistance in $T$. absoluta to both spino- sad and chlorantraniliprole insecticides. As a result, management options such as trapping and use of pheromones, cultural tactics (removal of infested leaves and fruits, using resistant tomato varieties, insect proof nets, soil solarization, destruction of alternative host weeds) and warning and early diagnosis (pheromone-based monitoring) are equally applied as important components within IPM packages in all different areas and the three time-intervals (Fig. 1). This indicates that these options, being less effective if applied alone, could be considered as permanent, complementary tools to other more effective options such as chemical control and/or biological control. In a future attempt to ensuring a more sustainable and effective pest management action, regardless of the invasion area, a promising research avenue would be to evaluate, in collaboration with farmers and their advisors, the effectiveness of various tool combinations, e.g., biopesticide application + release of parasitoids and/ or predators, pheromone mass trapping or mating disruption + biopesticide application, etc. Notably, in new invasion areas, parasitoids and predators would have to be discovered, evaluated and imported, which would bring in national or regional governmental efforts.

Figure 1 Diagrams on the proportion among control strategies employed within integrated pest management packages against Tuta absoluta in the native (< 2006), early-invaded (2006-2012) and recently (> 2012) invaded ranges, during three time intervals 


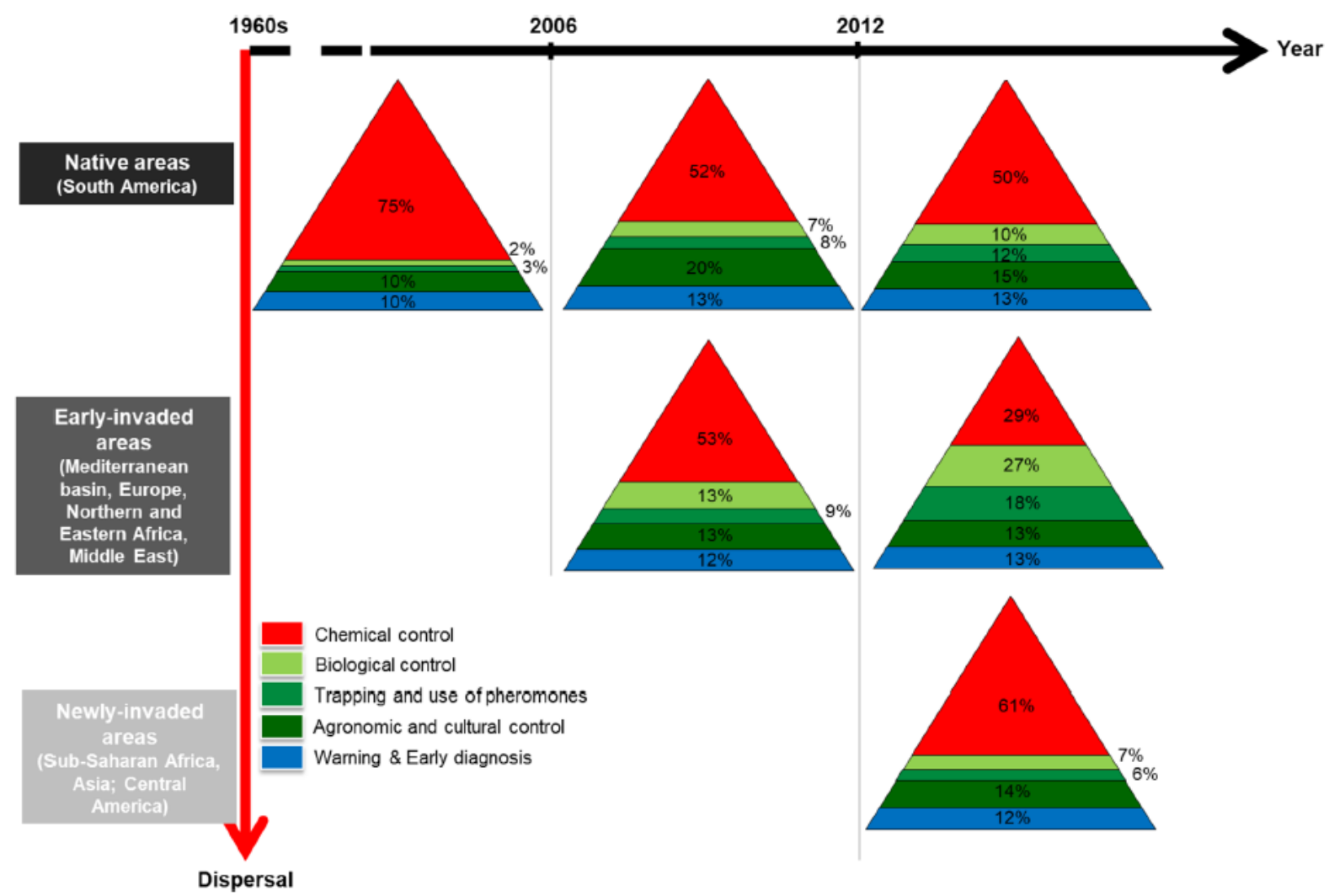

The temporal and geographical evolution of IPM programs is in line with the concept of prioritizing those pest control tactics that consider their relative environmental impact, as stated in Kogan and Bajwa (1999). These authors also emphasized that adoption of IPM is conceived at three levels of integration, starting with systems based on a single tactical approach such as using economic thresholds for better timing of pesticide applications, but later replacing that control measure with non-chemical tactics such as biological control and/or cultural control methods. It is encouraging to note that such a trend has already been shown in the native range and the early-invaded range (Fig. 1). Thus, following this approach, it is expected that in the near future and in light of important progresses made on $T$. absoluta management, the use of chemical control can be drastically reduced, mostly in developing countries and that new phytosanitary alternatives must be promoted.

\section{Current challenges for farmers}

Based on the questionnaires performed in collaboration with South American farmers and plant protection professionals, the current challenges for farmers in $T$. absoluta native range countries (Brazil, Argentina and Colombia) are mainly linked to the high economic cost associated with over-use of chemical insecticides and to the adoption of alternative non-chemical, eco-friendly management options (Table S1).

In early-invaded countries in Europe, farmers currently have major concerns about the high cost associated with multiple sprays of pesticides, the absence or lack of knowledge on the occurrence and biology of $T$. absoluta, the high cost associated with alternative non-chemical techniques, the development of resistance to spinosad and chlorant-raniliprole, the adverse 
effect of the omnivorous predatory bug $N$. tenuis whenever acting as a crop pest, the detrimental side effects of synthetic pesticides on predators such as $N$. tenuis and $M$. pygmaeus in greenhouses, and finding suitable techniques for minimizing or eliminating pesticide residues, as required by the European and international market (Table S2). Regarding early-invaded countries in the Middle

Eastern/North African region, current challenges for farmers are not very different from those stated earlier, linked to European countries (Table S2). Indeed, in Tunisia, Morocco, Saudi Arabia and Turkey, the main current challenges for managing $T$. absoluta mainly include the high cost associated with multiple sprays of pesticides, the observed control failure by the active ingredients used due to development of pest's resistance, the high cost associated with alternative non-chemical control options and the problematic adverse side effects of insecticides on predatory mirid bugs.

In newly invaded countries located either in sub-Saharan Africa, Asia or Central America, the absence or lack of knowledge on the occurrence and biology of the pest, the high cost associated with multiple insecticide sprays, the high cost associated with alternative nonchemical techniques, the control failure after several chemical insecticide applications, the negative side effects of insecticides on various ecosystem components as well as on farmers and consumers and the lack of awareness on the correct use of insecticides represent the most common current challenges for farmers (Table S3).

Therefore, we conclude that the current challenges for farmers for effectively managing this pest are continentindependent within the same range, but could be considered as continent or country dependent among the three diffeent areas (native, early invaded and newly invaded) that are characterized by different agro-ecosystems that could influence the pest's occurrence and bio-ecology. This is reported despite the existence of some similarities in farmers' general perceptions and trends in the three different areas. From this perspective, it should be pointed out that another potential challenge, i.e., the global impact of climate change on both the pest's bio-ecology and the already implemented management approaches, could come into focus in the near future in all concerned areas.

\section{Farmers' expectations from researchers}

Farmers in native range countries have expressed similar expectations from researchers, which are mainly linked to development of novel sustainable alternatives to chemical insecticides despite the promising control performance by insecticides in South America. This is mainly due to the frequent occurrence of resistant populations to several active ingredients used there, especially when considering that $T$. absoluta has been present in tomato-producing areas for a long time (Table S1)

As shown in Table S2, expectations from researchers are not quite different between European and North African/ Middle Eastern farmers belonging to early-invaded countries. In the latter, the most common expectations from the questionnaires are to find out sustainable solutions to both the pest's resistance to some chemical pesticides and phytophagy of the predator $N$. tenuis that frequently causes plant damage and to further promote biological control as a primary alternative to chemical control. This can be formed either through identification and assessment of effective natural enemies or via development, registration and commercialization of novel effective microbial insecticides and insect growth regulators (IGRs). Besides, testing and recommending effective and economically profitable bio- rational pest management combinations by 
researchers is considered a future task of utmost importance for farmers in early-invaded countries.

In contrast to native and early-invaded areas, as management strategies for $T$. absoluta are still in progress in African, Asian and Central American newly invaded countries, finding a solution to the pest's resistance to pesticides is not currently considered a research expectation from farmers (Table S3). In these geographical areas where the pest is still spreading in most tomatoproducing regions, providing recommendations on the most effective, but selective, chemical insecticides to control $T$. absoluta, developing cheaper biora- tional chemical-free alternatives such as the use of microbial pesticides and breeding resistant tomato cultivars constitute the most common research expectations from farmers.

Hence, apparently, farmers' expectations from researchers is area and time period dependent because in some (native and early-invaded) areas, researchers already tested and recommended to implement the most suitable pest management approaches, but this has not been yet achieved in the newly invaded area where further time would be necessary to better evaluate the pest status and spread, its bio-ecology as well as overall agro-ecological and economic impacts following the invasion by $T$. absoluta.

\section{Conclusions}

We offer a timely review on the up-to-date development and practical implementation of IPM programs targeting $T$. absoluta. While chemical control could be suggested for limited use, owing to its multifaceted side effects as well as rapid development of insecticide resistance by the pest, many advances were made on the fundamental and applied research related to either biological or biotechnical control. Specifically, the combined use of different management options has been largely tested under greenhouse conditions, which have achieved satisfactory IPM goals (Biondi et al. 2018). Agronomic control-related research is an emerging and fertile area where modulation of soil fertilization and/or irrigation, as well as the breeding of resistant cultivars are very likely to enhance the efficacy of IPM (Han et al. 2019b). In practice, the IPM programs evolved along with the range and time of invasion. The lessons and knowledge gathered from the native range and/or early-invaded areas will be useful for the relevant stakeholders in newly invaded areas. The biggest challenges for worldwide tomato growers, while they may somehow differ across continents, are the control failures by chemical pesticides and the high cost associated with biological and biotechnical control techniques (until further research to lower costs). Accordingly, researchers are expected to break the bottlenecks of some key issues that could enable lowering application costs, e.g., how to improve the biological control via increasing the mass-rearing capacity of key biocontrol agents and biocontrol efficacy in the field. Another challenging issue is the low extension/transfer ratio of the research findings from the research institutions to the actual stakeholders and farmers, which hints to the important roles of national agricultural administrations and local government in increasing the dissemination of effective control tactics against the pest.

\section{Authors' contributions}

$\mathrm{ND}, \mathrm{PH}$ and $\mathrm{AB}$ conceived and designed the work. ND, PH, RM, AB, JA, TB, MRC, AC, RNCG, JK, KAJK, AVL, MGL, MPH, AU, FJV and LZ provided text based on bibliography review. ND, $\mathrm{PH}, \mathrm{RM}, \mathrm{AB}, \mathrm{KA}, \mathrm{AA}, \mathrm{JA}, \mathrm{YB}, \mathrm{FC}, \mathrm{AC}, \mathrm{RDV}, \mathrm{FE}, \mathrm{DMF}, \mathrm{KH}, \mathrm{KI}, \mathrm{MJH}, \mathrm{CCJ}, \mathrm{MK}, \mathrm{HTL}, \mathrm{HM}, \mathrm{TM}$, 
AM, GM, SAM, RSN, AO, CR, MR, ER, PRS, FHW, MHW, SW and YBZ provided original information on current and past IPM Tuta absoluta strategies. ND, PH, RM and AB analyzed and presented the data. All authors revised and approved the manuscript.

Supplementary Information The online version contains supplementary material available at https://doi.org/10.1007/s10340-021-01442-8.

Funding Not applicable.

Availability of data and material Not applicable.

Code availability Not applicable.

\section{Declarations}

Conflict of interest The authors declare no conflict of interests.

Ethical approval This article does not contain any studies with human participants or animals (other than insects) performed by any of the authors. 


\section{References}

Abbes K, Biondi A, Zappalà L, Chermiti B (2014) Fortuitous parasitoids of the invasive tomato leafminer Tuta absoluta in Tunisia. Phytoparasitica 42:85-92

Abd El-Ghany NM, Abdel-Wahab ES, Ibrahim SS (2016) Population fluctuation and evaluation the efficacy of pheromone-based traps with different color on tomato leafminer moth, Tuta absoluta (Lepidoptera: Gelechiidae) in Egypt. Res J Pharm, Biol and Chemi Sci 7:1533-1539

Agudelo LA, Kaimowitz D (1997) Tecnologia agricola sostenible: retos institucionales y metodologicos. Dos estudios de caso en Colombia. Instituto interamericano de Cooperation para la Agricultura (IICA)/Deutsche Gesellschaftfür Technische Zusammenarbeit (GTZ) GmbH. San José, Costa Rica

Agusti N, Castané C, Fraile I, Alomar O (2020) Development of a PCR-based method to monitor arthropod dispersal in agroecosystems: Macrolophus pygmaeus (Hemiptera: Miridae) from banker plants to tomato crops. Insect Sci 27:1125-1134

Ahmed HAA, Onarici S, Bakhsh A, Akdogan G, Karakoç OC, Ozcan SF et al (2017) Targeted expression of insecticidal hybrid SN19 gene in potato leads to enhanced resistance against Colorado potato beetle (Leptinotarsa decemlineata Say) and tomato leafminer (Tuta absoluta Meyrick). Plant Biotechnol Rep 11:315-329

Aigbedion-Atalor PO, Mohamed SA, Hill MP, Zalucki MP, Azrag AGA, Srinivasan R et al (2020) Host stage preference and performance of Dolichogenidea gelechiidivoris (Hymenoptera: Braconidae), a candidate for classical biological control of Tuta absoluta in Africa. Biol Control 144:104215

Aktar MW, Sengupta D, Chowdhury A (2009) Impact of pesticides use in agriculture: their benefits and hazards. Interdiscip Toxicol 2:1-12

Albajes R, Alomar O (1999) Current and potential use of polyphagous predators. In: Albajes R, Gullino $M L$, van Lenteren JC, Elad Y (eds) Integrated Pest and Disease Management in Greenhouse Crops. Kluwer Academic Publishers, Dordrecht, The Netherlands, pp 265-275

Allegrucci N, Velazquez MS, Russo ML, Perez E, Scorsetti AC (2011) Endophytic colonisation of tomato by the entomopathogenic fungus Beauveria bassiana: the use of different inoculation techniques and their effects on the tomato leafminer Tuta absoluta (Lepidoptera: Gelechiidae). J Plant Prot Res $57: 205-211$

Alomar O, Goula M, Albajes $R$ (2002) Colonisation of tomato fields by predatory mirid bugs (Hemiptera: Heteroptera) in northern Spain. Agri Eco Env 89:105-115

Alsaedi G, Ashouri A, Talaei-Hassanloui $R$ (2017) Assessment of two Trichogramma species with Bacillus thuringiensis var. krustaki for the control of the tomato leafminer Tuta absoluta Meyrick (Lepidoptera: Gelechiidae) in Iran. Open J Ecol 7:112-124

Ardanuy A, Figeras M, Matas M, Madeira F, Arno J, Alomar O et al (2018) Local and landscape context influence precocity of tomato greenhouse colonization by predatory mirid bugs. In press, IOBC/WPRS Bull

Arno J, Gabarra $R$ (2011) Side effects of selected insecticides on the Tuta absoluta (Lepidoptera: Gelechiidae) predators Macrolophus pygmaeus and Nesidiocoris tenuis (Hemiptera: Miridae). J Pest Sci 84:513-520

Arno J, Sorribas R, Prat $M$ et al (2009) Tuta absoluta, a new pest in IPM tomatoes in the northeast of Spain. IOBC/WPRS Bull 49:203-208

Arno J, Castané C, Alomar O, Riudavets J, Agusti N, Gabarra R et al (2018a) Forty years of biological control in Mediterranean tomato greenhouses: The story of success. Isr J Entomol 48:209-226 
Arno J, Oveja MF, Gabarra $R$ (2018b) Selection of flowering plants to enhance the biological ontrol of Tuta absoluta using parasitoids. Biol Control 122:41-50

Arno J, Gabarra R, Molina P, Godfrey KE, Zalom FG (2019) Tuta absoluta (Lepidoptera: Gelechiidae) success on common Solanaceous species from California tomato production areas. Environ Entomol 48:1394-1400

Attygalle $A B$, Jham GN, Svatos A, Frighetto RTS, Ferrara FA, Vilela EF, Uchôa-Fernandes MA, Meinwald J (1996) 3E,8Z,11Z)-3,8,11-tetradecatrienyl acetate, major sex pheromone component of the tomato pest Scrobipalpuloides absoluta (Lepidoptera: Gelechiidae. Bioorg Med Chem 4:305-314

Aviron S, Poggi S, Varennes Y-D, Lefèvre A (2016) Local landscape heterogeneity affects crop colonization by natural enemies of pests in protected horticultural cropping systems. Agric Ecosyst Environ 227:1-10

Bacci L, Silva ÉM, Silva GA, Silva LJ, Rosado JF, Samuels RI et al (2018) Natural mortality factors of tomato leafminer Tuta absoluta in open-field tomato crops in the South America. Pest Manag Sci 75:736743

Balmford A, Bennun L, Ten Brink B, Cooper D, Côté IM et al (2005) The convention on biological diversity's 2010 target. Science 307:212-213

Balzan MV (2017) Flowering banker plants for the delivery of multiple agroecosystem services. Arthropod Plant Interact 11:743-754

Barbosa WF, Smagghe G, Guedes RNC (2015) Pesticides and reduced- risk insecticides, native bees and pantropical stingless bees: pitfalls and perspectives. Pest Manag Sci 71:1049-1053

Batalla-Carrera L, Morton A, Garcfa-del-Pino F (2010) Efficacy of entomopathogenic nematodes against the tomato leaf miner Tuta absoluta in laboratory and greenhouse conditions. Biocontrol 55:523-553

Benelli G, Pavelab R, Zorzettoc C, Sânchez-Mateoc CC, Santinid G, Canalea A et al (2019) Insecticidal activity of the essential oil from Schizogyne sericea (Asteraceae) on four insect pests and two non-target species. Entomol Gen 39:9-18

Benvenga SR, Gravena FOA, S, (2007) Decision making for integrated pest management of the South American tomato pinworm based on sexual pheromone traps. Hortic Bras 25:164-169

Biondi A, Desneux N, Siscaro G, Zappalà L (2012) Using organic-certified rather than synthetic pesticides may not be safer for biological control agents: selectivity and side effects of 14 pesticides on the predator Orius laevigatus. Chemosphere 87:803-812

Biondi A, Desneux N, Amiens-Desneux E, Siscaro G, Zappalà L (2013) Biology and developmental strategies of the Palaearctic parasitoid Bracon nigricans (Hymenoptera: Braconidae) on the Neotropical moth Tuta absoluta (Lepidoptera: Gelechiidae). J Econ Entomol 106:1638-1647

Biondi A, Zappalà L, Desneux N, Aparo A, Siscaro G, Rapisarda C et al (2015) Potential toxicity of acypermethrin-treated nets on Tuta absoluta (Lepidoptera: Gelechiidae). J Econ Entomol 108:1191-1197

Biondi A, Zappalà L, Di Mauro A, Garzia GT, Russo A, Desneux N (2016) Can alternative host plant and prey affect phytophagy and biological control by the zoophytophagous mirid Nesidiocoris tenuis? Biocontrol 61:79-90

Biondi A, Guedes RNC, Wan F, Desneux N (2018) Ecology, Worldwide Spread, and Management of the Invasive South American Tomato Pinworm, Tuta absoluta: Past, Present, and Future. Annu Rev Entomol 63:239-258

Bompard A, Jaworski CC, Bearez P, Desneux N (2013) Sharing a predator: can an invasive alien pest affect the predation on a local pest? Pop Ecol 55:433-440

Buitenhuis R, Shipp JL (2005) Efficacy of entomopathogenic nematode Steinernema feltiae (Rhabditida: 
Steinernematidae) as influenced by Frankliniella occidentalis (Thysanoptera: Thripidae) developmental stage and host plant stage. J Econ Entomol 98:1480-1485

Cabello T, Gallego JR, Vila E, Soler A, del Pino M, Carnero A, Hernandez-Suarez E, Polaszek A (2009) Biological control of the South American tomato pinworm, Tuta absoluta (Lep.: Gelechii- dae), with releases of Trichogramma achaeae (Hym.: Trichogrammatidae) in tomato greenhouses of Spain. IOBC WPRS Bull 49:225-230

Cabello T, Bonfil F, Gallego JR, Fernandez FJ, Gamez M, Garay J (2015) Can interactions between an omnivorous hemipteran and an egg parasitoid limit the level of biological control for the tomato pinworm? Environ Entomol 44:12-26

Calvo J, Bolckmans K, Stansly PA, Urbaneja A (2009) Predation by Nesidiocoris tenuis on Bemisia tabaci and injury to tomato. Biocontrol 54:237-246

Calvo FJ, Bolckmans K, Belda JE (2012a) Release rate for a preplant application of Nesidiocoris tenuis for Bemisia tabaci control in tomato. Biocontrol 57:809-817

Calvo FJ, Lorente MJ, Stansly PA, Belda JE (2012b) Preplant release of Nesidiocoris tenuis and supplementary tactics for control of Tuta absoluta and Bemisa tabaci in greenhouse tomato. Entomol Exp Appl 143:111-119

Calvo FJ, Soriano JD, Stansly PA, Belda JE (2016) Can the parasitoid Necremnus tutae (Hymenoptera: Eulophidae) improve existing biological control of the tomato leafminer Tuta aboluta (Lepidoptera: Gelechiidae)? Bull Entomol Res 106:502-511

Campolo O, Cherif A, Ricupero M, Siscaro G, Grissa-Lebdi K, Russo A et al (2017) Citrus peel essential oil nanoformulations to control the tomato borer, Tuta absoluta: chemical properties and biological activity. Sci Rep 7:13036

Campolo O, Puglisi I, Barbagallo RN, Cherif A, Ricupero M, Biondi A, Zappalà L (2020) Side effects of two citrus essential oil formulations on a generalist insect predator, plant and soil enzymatic activities. Chemosphere 257:127252

Campos MR, Rodrigues ARS, Silva WM, Silva TBM, Silva VRF, Guedes RNC et al (2014) Spinosad and the tomato borer Tuta absoluta: A bioinsecticide, an invasive pest threat, and high insecticide resistance. PLOS ONE 9:e103235

Campos MR, Silva TBM, Silva WM, Silva JE, Siqueira HAA (2015) Spinoyn resistance in the tomato borer Tuta absoluta (Meyrick) (Lepidoptera: Gelechiidae). J Pest Sci 88:405-412

Campos MR, Biondi A, Adiga A, Guedes RNC, Desneux N (2017) From the Western Palaearctic region to beyond: Tuta absoluta 10 years after invading Europe. J Pest Sci 90:787-796

Campos MR, Béarez P, Amiens-Desneux E, Ponti L, Gutierrez AP et al (2021a) Thermal biology of Tuta absoluta: demographic parameters and facultative diapause. J Pest Sci 94:829-842

Campos MR, Amiens-Desneux E, Béarez P, Soares MA, Ponti L et al (2021b) Impact of low temperature and host plant on Tuta absoluta. Entomol Exp App. https://doi.org/10.1111/eea.13094

Caparros-Megido R, Haubruge E, Verheggen FJ (2012) First evidence of deuterotokous parthenogenesis in the tomato leafminer, Tuta absoluta (meyrick) (Lepidoptera: Gelechiidae). J Pest Sci 85:409-412

Caparros-Megido R, Haubruge E, Verheggen FJ (2013) Pheromonebased management strategies to control the tomato leafminer, Tuta absoluta (Lepidoptera: Gelechiidae). A review. Biotech- nol Agron Soc Environ 17:475-482

Cardé RT, Minks AK (1995) Control of moth pests by mating disruption: successes and constraints. Annu Rev Entomol 40:559-585 
Carpio C, Dangles O, Dupas S, Léry X, Lopez-Ferber M, Orbe K, Zeddam JL (2012) Development of a viral biopesticide for the control of the Guatemala potato tuber moth Tecia solanivora. J Invertebr Pathol 112:184-219

Cascone P, Carpenito S, Slotsbo S, lodice L, SØrensen JG, Holmstrup M, Guerrieri E (2015) Improving the efficiency of Trichogramma achaeae to control Tuta absoluta. Biocontrol 60:761-771

Castané C, Alomar O, Goula M, Gabarra R (2004) Colonization of tomato greenhouses by the predatory mirid bugs Macrolophus caliginosus and Dicyphus tamaninii. Biol Control 30:591-597

Castané C, Arno J, Gabarra R, Alomar O (2011) Plant damage to vegetable crops by zoophytophagous mirid predators. Biol Control 59:22-29

Castresana J, Puhl L (2017) Comparative study among a variety of solar-powered LED traps to capture tomato leafminers tuta abso- luta adults by mass trapping in tomato greenhouses in the province of entre nos, argentina. Idesia (arica) 35:87-95

Chailleux A, Desneux N, Seguret J, Khanh HDT, Maignet P, Tabone E (2012) Assessing European egg parasitoids as a mean of controlling the invasive south american tomato pinworm Tuta absoluta. PLoS ONE 7:e48068

Chailleux A, Biondi A, Han P, Tabone E, Desneux N (2013a) Suitability of the pest-plant system Tuta absoluta (Lepidoptera: Gelechiidae)-tomato for Trichogramma (Hymenoptera: Trichogrammatidae) parasitoids and insights for biological control. J Econ Entomol 106:2310-2321

Chailleux A, Bearez P, Pizzol J, Amiens-Desneux E, Ramirez-Romero R, Nesneux N (2013b) Potential for combined use of parasitoids and generalist predators for biological control of the key invasive tomato pest Tuta absoluta. J Pest Sci 86:533-541

Chailleux A, Mohl EK, Teixeira-Alves M, Messelink GJ, Desnuex N (2014a) Natural enemy-mediated indirect interactions among prey species: potential for enhancing biocontrol services in agroecosystems. Pest Manag Sci 70:1769-1779

Chailleux A, Desneux N, Arno J, Gabarra R (2014b) Biology of two key Palaearctic larval ectoparasitoids when parasitizing the invasive pest Tuta absoluta. J Pest Sci 87:441-448

Chang PEC, Metz MA (2021) Classification of Tuta absoluta (Meyrick, 1917) (Lepidoptera: Gelechiidae: Gelechiinae: Gnorimo- schemini) based on cladistic analysis of morphology. P Entomol Soc Wash 123:4154

Chegini SG, Abbasipour H (2017) Chemical composition and insecticidal effects of the essential oil of cardamom, Elettaria car- damomum on the tomato leaf miner, Tuta absoluta. Toxin Rev 36:12-17

Chen XP, Cui ZL, Fan MS, Vitousek P, Zhao M, Ma W et al (2014) Producing more grain with lower environmental costs. Nature 514:486-489

Cherif A, Harbaoui K, Zappalà L, Grissa-Lebdi K (2018) Efcacy of mass trapping and insecticides to control T. absoluta in Tunisia. J Plant Dis Prot 125:51-61

Cherif A, Attia-Barhoumi S, Mansour R, Zappalà L, Grissa-Lebdi K (2019a) Elucidating key biological parameters of Tuta absoluta on different host plants and under various temperature and relative humidity regimes. Entomol Gen 39:1-7

Cherif A, Mansour R, Barhoumi-Attia S, Zappalà L, Grissa-Lebdi K (2019b) Effectiveness of different release rates of Trichogramma cacoeciae (Hymenoptera: Trichogrammatidae) against Tuta absoluta (Lepidoptera: Gelechiidae) in protected and open field tomato crops in Tunisia. Bioc Sci Techn 29:149-161

Cherif A, Mansour R, Grissa-Lebdi K (2021) The egg parasitoids Trichogramma: from laboratory mass rearing to biological control of lepidopteran pests. Biocontrol Sci Techn. https://doi.org/ 10.1080/09583157.2020.1871469 
Chermiti B, Abbes $K$ (2012) Comparison of pheromone lures used in mass trapping to control the tomato leafminer Tuta absoluta (Meyrick, 1917) in industrial tomato crops in Kairouan (Tunisia). Bull OEPP 42:241-248

Ciceoi R, Gutue M (2020) Updated List of Host Plants of Tuta absoluta (Meyrick, 1917) (Lepidoptera: Gelechiidae) with Reference to Romania. Acta Zool Bulg 72:597-610

Cocco A, Deliperi S, Delrio G (2012) Potential of mass trapping for Tuta absoluta management in greenhouse tomato crops using light and pheromone traps. IOBC-WPRS Bull 80:319-324

Cocco A, Deliperi S, Delrio G (2013) Control of Tuta absoluta (Meyrick) (Lep., Gelechiidae) in greenhouse tomato crops using the mating disruption technique. J Appl Entomol 137:16-28

Contreras J, Mendoza JE, Martinez-Aguirre MR, Garda-Vidal L, Izquierdo J, Bielza P (2014) Efficacy of enthomopathogenic fungus Metarhizium anisopliae against Tuta absoluta (Lepidoptera: Gel- echiidae). J Econ Entomol 107:121-124

Cooper J, Dobson H (2007) The benefits of pesticides to mankind and the environment. Crop Prot 26:1337-1348

Crisol E, van der Blom J (2018) La avispa parasitoide Necremnus tutae lidera la lucha contra Tuta absoluta en primavera. https:// coexphal.wordpress.com/2018/04/10/la-avispa-parasitoide- necremnustutae-lidera-la-lucha-contra-tuta-absoluta-en-prima vera. Accessed 11.09.2018

Dara SK (2019) Non-entomopathogenic roles of entomopathogenic fungi in promoting plant health and growth. Insects 10:277

de Oliveira CM, de Oliveira JV, Barbosa DR, e S, Breda MO, Franca SM de, Duarte BLR, (2017) Biological parameters and thermal requirements of Trichogramma pretiosum for the management of the tomato fruit borer (Lepidoptera: Crambidae) in tomatoes. Crop Prot 99:39-44

Deligeorgidis NP, Kavallieratos NG, Malesios C, Sidiropoulos G, Deligeorgidis PN, Benelli $G$, Papanikolaou NE (2019) Evaluation of combined treatment with mineral oil, fenoxycarb and chlorpyrifos against Cydia pomonella, Phyllonorycter blan- cardella and Synanthedon myopaeformis in apple orchards. Entomol Gen 39:117-126

Desneux N, O'Neil RJ (2008) Potential of an alternative prey to disrupt predation of the generalist predator, Orius insidiosus, on the pest aphid, Aphis glycines, via short-term indirect interactions. Bull Entomol Res 98:631-639

Desneux N, Decourtye A, Delpuech J (2007) The sublethal effects of pesticides on beneficial arthropods. Annu Rev Entomol 52:81-106

Desneux N, Wajnberg E, Wyckhuys KAG, Burgio G, Arpaia S, Narvâez-Vasquez CA (2010) Biological invasion of European tomato crops by Tuta absoluta: Ecology, geographic expansion and prospects for biological control. J Pest Sci 83:197-215

Desneux N, Luna MG, Guillemaud T, Urbaneja A (2011) The invasive South American tomato pinworm, Tuta absoluta, continues to spread in Afro-Eurasia and beyond: the new threat to tomato world production. J Pest Sci 84:403-408

Desneux N, Kaplan I, Yoo HJS, Wang S, O'Neil RJ (2019) Temporal synchrony mediates the outcome of indirect effects between prey via a shared predator. Entomol Gen 39:127-136

Dong YC, Han P, Niu CY, Zappalà L, Amiens-Desneux E, Bearez P, Lavoir AV, Biondi A, Desneux N (2018) Nitrogen and water inputs to tomato plant do not trigger bottom-up effects on a leafminer parasitoid through host and non-host exposures. Pest Manag Sci 74:516-522

Ebssa L, Borgemeister C, Poehling HM (2004) Effectiveness of different species/strains of entomopathogenic nematodes for control of western flower thrips (Frankliniella occidentalis) at various 
concentrations, host densities, and temperatures. Biol Control 29:145-154

El-Arnaouty SA, Pizzol J, Galal HH, Kortam MN, Afifi Al, Beyssat V, Desneux N, Biondi A, Heikal IH (2014) Assessment of two Trichogramma species for the control of Tuta absoluta in North African tomato greenhouses. Afr Entomol 22:801-809

EPPO (2021) https://gd. eppo. int/taxon/GNORAB/distribution. Accessed on 9 June 2021

Ferracini C, Bueno VHP, Dindo ML, Ingegno BL, Luna MG, Gervassio NGS et al (2019) Natural enemies of Tuta absoluta in the Mediterranean basin, Europe and South America. Biocontrol Sci Techn 29:578-609

Ferrara FAA, Vilela EF, Jham GN, Eiras AE, Picanço MC, Attygalle AB et al (2001) Evaluation of the synthetic major component of the sex pheromone of Tuta absoluta (Meyrick) (Lepidoptera: Gelechiidae). $J$ Chem Ecol 27:907-917

Folcia AM (2013) Evaluacion de Pseudapantelesdignus (Hymenoptera-Braconidae) como posible agente de control biologico de

Tuta absoluta (Lepidoptera-Gelechidae), plaga clave del cul- tivo de tomate en los alrededores del Gran Buenos Aires. PhD Dissertation, Universidad de Buenos Aires, Argentina.

Gabarra R, Alomar O, Castane C, Guola M, Albajes R (2004) Movement of greenhouse whitefly and its predators between in- and outside of Mediterranean greenhouses. Agric Ecosyst Environ 102:341-348

Gabarra R, Zapata R, Castané C, Riudavets J, Arno J (2006) Releases of Eretmocerus mundus and Macrolophus caliginosus for controlling Bemisia tabaci on spring and autumn greenhouse tomato crops. IOBC/WPRS Bull 29:71-76

Gabarra R, Arno J, Lara L, Verdu MJ, Ribes A, Beitia F et al (2014) Native parasitoids associated with Tuta absoluta in the tomato production areas of the Spanish Mediterranean Coast. Biocontrol 59:45-54

Gebiola M, Bernardo U, Ribes A, Gibson GAP (2015) An integrative study of Necremnus Thomson (Hymenoptera: Eulophidae) associated with invasive pests in Europe and North America: taxonomic and ecological implications. Zool J LinnSoc-Lond 173:352-423

Giustolin TA, Vendramim JD, Alves SB, Pereira VSARM (2001) Susceptibility of Tuta absoluta (Meyrick) (Lep., Gelechiidae) reared on two species of Lycopersicon to Bacillus thuringiensis var. kurstaki. J Appl Entomol 125:551-556

Goda NF, El-Heneidy AH, Djelouah K, Hassan N (2015) Integrated pest management of the tomato leafminer, Tuta absoluta (Meyrick) (Lepidoptera: Gelechiidae) in tomato fields in Egypt. Egypt J Biol Pest Cont 25:655-661

Gomez-Valderrama JA, Barrera G, Lopez-Ferber M, Belaich M, Ghiringhelli PD, Villamizar L (2017) Potential of betabaculoviruses to control the tomato leafminer Tuta absoluta (Meyrick). J Appl Entomol 142:67-77

Gontijo PC, Picanço MC, Pereira EJG, Martins JC, Chediak M, Guedes RNC (2013) Spatial and temporal variation in the control failure likelihood of the tomato leaf miner, Tuta absoluta. Ann Appl Biol 162:50-59

Gonzalez PE (2003) Efectos de insecticidasusados en el control de Cydiapomonella y Tuta absoluta, sobre los parasitoides de huevo Trichogramma nerudai y Trichogramma pretiosum. Ph. D. thesisdissertation. Universidad de las Américas, Fac. de CienciasA- gropecuarias, Santiago, Chile

Gonzalez-Cabrera J, Molla O, Monton H, Urbaneja A (2011) Efficacy of Bacillus thuringiensis (Berliner) in controlling the tomato borer, Tuta absoluta (Meyrick) (Lepidoptera: Gelechiidae). Biocontrol 56:71-80

Griepink FC, Van-Beek TA, Posthumus MA, De-Groot A, Visser JH, Voerman S (1996) Identification of the sex pheromone of scrobipalpula absolute; determination of double bond positions in triple unsaturated 
straight chain molecules by means of dimethyl disulphide derivatization. Tetrahedron Lett 37:411-414

Guedes RNC (2017) Insecticide Resistance, Control Failure Likelihood and the First Law of Geography. Pest Manag Sci 73:479-484

Guedes RNC, Picanço MC (2012) The tomato borer Tuta absoluta in South America: pest status, management and insecticide resistance. EPPO Bull 42:211-216

Guedes RNC, Siqueira HAA (2012) The tomato borer Tuta absoluta: Insecticide resistance and control failure. CAB Rev Perspect Agric Vet Sci Nutr Nat Resour 7:1-7

Guedes RNC, Smagghe G, Stark JD, Desneux N (2016) Pesticide- induced stress in arthropod pests for optimized integrated pest management programs. Annu Rev Entomol 61:1-20

Guedes RNC, Walse SS, Throne JE (2017) Sublethal exposure, insecticide resistance, and community stress. Curr Opin Insect Sci 27:47-53

Guedes RNC, Roditakis E, Campos MR, Haddi K, Bielza P, Siqueira HAA et al (2019) Insecticide resistance in the tomato pinworm Tuta absoluta: patterns, spread, mechanisms, management and outlook. J Pest Sci 92:1329-1342

Gugliuzzo A, Biedermann PH, Carrillo D, Castrillo LA, Egonyu JP et al (2021) Recent advances toward the sustainable management of invasive Xylosandrus ambrosia beetles. J Pest Sci 94:615-637

Guillemaud T, Blin A, Le Goff I, Desneux N, Reyes M et al (2015) The tomato borer, Tuta absoluta, invading the Mediterranean Basin, originates from a single introduction from Central Chile. Sci Rep 5:8371

Haddi K, Berger M, Bielza P, Cifuentes D, Field LM, Gorman K et al (2012) Identification of mutations associated with pyrethroid resistance in the voltage-gated sodium channel of the tomato leaf miner (Tuta absoluta). Insect Biochem Mol Biol 42:506-513

Haddi K, Berger M, Bielza P, Rapisarda C, Williamson MS, Moores G (2017) Mutation in the ace-1 gene of the tomato leaf miner (Tuta absoluta) associated with organophosphates resistance. J Appl Entomol 141:612-619

Han P, Lavoir AV, Le Bot J, Amiens-Desneux E, Desneux N (2014) Nitrogen and water availability to tomato plants triggers bottom- up effects on the leafminerTuta absoluta. Sci Rep 4:4455

Han P, Bearez P, Adamowicz S, Lavoir AV, Desneux N (2015a) Nitrogen and water limitations in tomato plants trigger negative bottom-up effects on the omnivorous predator Macrolophus pygmaeus. $J$ Pest Sci 88:685-691

Han P, Dong YC, Lavoir AV, Adamowicz S, Bearez P, Wajnberg E, Desneux N (2015b) Effect of plant nitrogen and water status on the foraging behavior and fitness of an omnivorous arthropod. Ecol Evol 5:5468-5477

Han P, Desneux N, Amiens-Desneux E, Le Bot J, Bearez P, Lavoir AV (2016) Does plant cultivar difference modify the bottom-up effects of resource limitation on plant-insect herbivore interactions? $J$ Chem Ecol 42:1293-1303

Han P, Zhang YN, Lu ZZ, Wang S, Biondi A, Desneux N (2018) Are we ready for the invasion of Tuta absoluta? Unanswered key questions for elaborating an Integrated Pest Management package in Xinjiang, China. Entomol Gen 38:113-125

Han P, Bayram Y, Shaltiel-Harpaz L, Sohrabi F, Saji A, Esenali UT et al (2019a) Tuta absoluta continues to disperse in Asia: damage, ongoing management and future challenges. J Pest Sci 92:13171327

Han P, Desneux N, Becker C, Larbat R, Le Bot J, Zhang J, Lavoir A (2019b) Bottom-up effects of irrigation, fertilization and plant resistance on Tuta absoluta: implications for Integrated Pest Management. J Pest Sci 92:1359-1370 
Han P, Becker C, Le Bot J, Larbat R, Lavoir AV, Desneux N (2020) Plant nutrient supply alters the magnitude of indirect interactions between insect herbivores: from foliar chemistry to community dynamics. J Ecol 108:1497-1510

Hassan N, Al-Zaidi S (2010) Tuta absoluta - pheromone mediated management strategy. Int Pest Control 52:158-160

Haye T, Girod P, Cuthberston AGS, Wang XG, Daane KM, Hoelmer KA et al (2016) Current SWD IPM tactics and their practical implementation in fruit crops across different regions around the world. $\mathrm{J}$ Pest Sci 89:643-651

Herrera RM, Rodriguez CD, Cantor $F$ (2018) Antecedentes y perspectivas para el manejo integrado de Tuta absoluta Meyrick 1917 (Lepidoptera: Gelechiidae). Revista Facultad De Ciencias Basi- cas 14:1-9

Howse PE, Stevens IDR, Jones OT (1998) Lure and kill. In: Insect Pheromones and their Use in Pest Management. Springer, Dordrecht

Huang NX, Jaworski CC, Desneux N, Zhang F, Yang PY, Wang S (2020) Long-term and large-scale releases of Trichogramma promote pesticide decrease in maize in northeastern China. Entomol Gen 40:331-335

Ismoilov K, Wang MH, Jalilov A, Zhang X, Lu ZZ, Saidov A et al (2020) First report using a native lacewing species to control Tuta absoluta: from laboratory trials to field assessment. Insects 11:286

Jamshidnia A, Abdoli S, Farrokhi S, Sadeghi R (2018) Efficiency of spinosad, Bacillus thuringiensis and Trichogramma brassicae against the tomato leafminer in greenhouse. Biocontrol 63:619-627

Jaworski CC, Chailleux A, Bearez P, Desneux N (2015) Predator- mediated apparent competition between pests fails to prevent yield loss despite actual pest populations decrease. J Pest Sci 88:793-803

Jones O (1998) Practical applications of pheromones and other semiochemicals. In: Howse P, Stevens I, Jones $O$ (eds) Insect pheromones and their use in pest management. Chapman \& Hall, London, pp 263355

Kader A, Hajj E, Rizk H, Gharib M, Houssein M, Talj V, Taha N et al (2017) Management of Tuta absoluta Meyrick (Lepidoptera: Gelechiidae) using biopesticides on tomato crop under greenhouse conditions. J Agric Sci 9:123-129

Kamali S, Karimi J, Koppenhofer AM (2018) New Insight into the Management of the Tomato Leaf Miner, Tuta absoluta (Lepidoptera: Gelechiidae) with entomopathogenic nematodes. J Econ Entomol 111:112-119

Keçeci M, Oztop A (2017) Possibilities for biological control of Tuta absoluta (Meyrick, 1917) (Lepidoptera: Gelechiidae) in the western Mediterranean Region of Turkey. Türk Entomol Derg 41:219230

Khidr AA, Gaffar SA, Nada MS, Taman AA, Salem FA (2013) New approaches for controlling tomato leafminer, Tuta abso- luta (Meyrick) in tomato fields in Egypt. Egypt J Agric Res 91:335-348

Klieber JA, Reineke A (2016) The entomopathogen Beauveria bassiana has epiphytic and endophytic activity against the tomato leaf miner Tuta absoluta. J Appl Entomol 140:80-589

Kogan M (1998) Integrated pest management: Historical perspectives and contemporary developments. Annu Rev Entomol 43:243-270

Kogan M, Bajwa WI (1999) Integrated Pest Management: A Global Reality? An Soc Entomol Brasil 28:1-25

Kohler H-R, Triebskorn R (2013) Wildlife ecotoxicology of pesticides: can we track effects to the population level and beyond? Science 341:759-765 
Kortam MN, El-Arnaouty SA, Afifi Al, Heikal IH (2014) Efficacy of different biological methods for controlling the tomato leaf miner, Tuta absoluta (Meyrick) (Lepidoptera: Gelechiidae) on tomato in greenhouse in Egypt. Egypt J Biol Pest Cont 24:523-528

Lacey L (2016) Microbial control of insect and mite pests: from theory to practice, 1 st edn. Academic Press, London

Lambion J (2011) Functional biodiversity in Southern France: a method to enhance predatory mirid bug populations. Acta Hort 915:165-170

Lambion J (2014) Flower strips as winter shelters for predatory Miridae bugs. Acta Hort 1041:149-156

Larrain P (1987) Plagas del tomate. I parte: Descripcion, fluctuacion poblacional, dano, plantas hospederas, enemigos naturales de las plagas principales. IPA La Platina 39:30-35

Lee MS, Albajes R, Eizaguirre M (2014) Mating behaviour of female Tuta absoluta (Lepidoptera: Gelechiidae): polyandry increases reproductive output. J Pest Sci 87:429-439

Lenfant C, Ridray G, Schoen L (2000) Biopropagation of Macrolophus caliginosus (Wagner) for a quicker establishment in southern tomato greenhouses. IOBC/WPRS Bull 23:241-246

Li XW, Li D, Zhang ZJ, Huang J, Zhang JM, Hafeez M et al (2020) Supercooling capacity and cold tolerance of the South American tomato pinworm, Tuta absoluta, a newly invaded pest in China. J Pest Sci. https://doi.org/10.1007/s10340-020-01301-y

Liebhold AM, Berec L, Brockerhoff EG, Epanchin-Niell RS, Hastings A, Herms DA et al (2016) Eradication of invading insect populations: From concepts to applications. Annu Rev Ento- mol 61:335352

Lietti MMM, Botto E, Alzogaray RA (2005) Insecticide resistance in Argentine populations of Tuta absoluta (Meyrick) (Lepidop- tera: Gelechiidae). Neotrop Entomol 34:113-119

Linn JCE, Campbell MG, Roelofs WL (1987) Pheromone components and active spaces: what do moths smell and where do they smell it? Science 237:650-652

Lobos E, Occhionero M, Werenitzky D, Fernandez J, Gonzalez LM, Rodriguez C et al (2013) Optimization of a trap for Tuta abso- luta Meyrick (Lepidoptera: Gelechiidae) and trials to determine the effectiveness of mass trapping. Neotrop Entomol 42:448-457

Lockwood JL, Hoopes MF, Marchetti MP (2013) Invasion Ecology, 2nd edn. Wiley, New York

Luna MG, Wada VI, Sanchez NE (2010) Biology of Dineulophus phthorimaeae (Hymenoptera: Eulophidae) and field interaction with Pseudapanteles dignus (Hymenoptera: Braconidae), larval parasitoids of Tuta absoluta (Lepidoptera: Gelechiidae) in tomato. Ann EntomolSoc Am 103:936-942

Mansour R, Biondi A (2021) Releasing natural enemies and applying microbial and botanical pesticides for managing Tuta absoluta in the MENA region. Phytoparasitica 49:179-194

Mansour R, Brévault T, Chailleux A, Cherif A, Grissa-Lebdi K, Haddi K et al (2018) Occurrence, biology, natural enemies and management of Tuta absoluta in Africa. Entomol Gen 38:83-111

Mansour R, Cherif A, Attia-Barhoumi S, Zappalà L, Grissa-Lebdi K (2019) Tuta absoluta in Tunisia: ten years of invasion and pest management. Phytoparasitica 47:461-474

Mascarin G, Alves SB, Rampelotti-Ferreira FT, Urbano MR, Demé- trio CGB, Delalibera I (2010) Potential of a granulovirus isolate to control Phthorimaea operculella (Lepidoptera: Gelechiidae). Biocontrol 55:657-671

McLaughlin GM, Dearden PK (2019) Invasive insects: management methods explored. J Insect Sci 19:17

McNitt J, Chungbaek YY, Mortveit H, Marathe M, Campos MR, Desneux N et al (2019) Assessing the 
multi-pathway threat from an invasive agricultural pest: Tuta absoluta in Asia. P R Soc B-Biol Sci 286:1-9

Medeiros MA, de Boas GLV, Vilela NJ, Carrijo OA (2009) A preliminary survey and biological control of South America tomato pinworm with the parasitois Trichogramma pretiosum in greenhouse models. Hortic Bras 27:80-85

Meissle M, Romeis J, Bigler F (2011) Bt maize and integrated pest management - a European perspective. Pest Manag Sci 67:1049-1058

Messelink GJ, Bennison J, Alomar O, Ingegno BL, Tavella L et al (2014) Approaches to conserving natural enemy populations in greenhouse crops: current methods and future prospects. Biocontrol 59:377393

Michereff-Filho M, Vilela EF, Jham GN, Attygalle A, Svatos A, Mein- wald J (2000) Initial studies of mating disruption of the tomato moth, Tuta absoluta (Lep., Gelechiidae) using synthetic sex pheromone. $J$ Braz Chem Soc 111:621-628

Miranda M, Picanço M, Zanuncio J, Guedes R (1998) Ecological life table of Tuta absoluta (Meyrick) (Lepidoptera: Gelechiidae). Biocontrol Sci Technol 8:597-606

Molla O, Monton H, Vanaclocha P, Beitia F, Urbaneja $A$ et al (2009) Predation by the mirids Nesidiocoris tenuis and Macrolophus pygmaeus on the tomato borer Tuta absoluta. IOBC/WPRS Bull 49:209-214

Mollâ O, Gonzâlez-Cabrera J, Urbaneja A (2011) The combined use of Bacillus thuringiensis and Nesidiocoris tenuis against the tomato borer Tuta absoluta. Biocontrol 56:883-891

Monserrat Delgado A (2008) La polilladel tomate Tuta absoluta en la region de Murcia: bases para su control. Ministry of Agriculture and Water, Murcia

Morales J, Munoz L, Rodriguez D, Cantor F (2014) Accion combinada de feromona sexual y de avispas Apanteles gelechiidivoris para el control de Tuta absoluta en cultivos de tomate. Acta Biol Colomb 19:175184

Moreau J, Buffenoir N, Thiéry D, Vogelweith $F$ (2019) Lobesia botrana as a preferred host of Campoplex capitator, the most occurring larval parasitoid in European vineyards. Entomol Gen 39:307312

Mutegi DM, Kilalo D, Kimenju JW, Waturu C (2017) Pathogenicity of selected native entomopathogenic nematodes against tomato leaf miner (Tuta absoluta) in Kenya. World J Agric Res 5:233-239

Naselli M, Zappala L, Gugliuzzo A, Garzia GT, Biondi A, Rapisarda C et al (2016) Olfactory response of the zoophytophagous mirid Nesidiocoris tenuis to tomato and alternative host plants. Arthropod Plant Interact 11:121-131

Nieves EL, Pereyra PC, Luna MG, Medone P, Sânchez NE (2015) Laboratory population parameters and field impact of the larval endoparasitoid Pseudapanteles dignus (Hymenoptera: Braconidae) on its host Tuta absoluta (Lepidoptera: Gelechiidae) in tomatocrops in Argentina. J Econ Entomol 108:15531559

Oztemiz S, Kutuk H, Portakaldali M (2012) Biological control of tomato leaf miner (Lepidoptera: Gelechiidae) on greenhouse- grown tomato in Turkey. J Entomol Sci 47:272-274

Paini DR, Sheppard AW, Cook DC, De Barro PJ, Worner SP, Thomas MB (2016) Global threat to agriculture from invasive species. Proc Natl Acad Sci USA 113:7575-7579

Parra JRP, Zucchi RA (2004) Trichogramma in Brazil: feasibility of use after 20 years of research. Neotrop Entomol 33:271-281

Pavela R, Benelli G (2016) Essential oils as ecofriendly biopesticides? Challenges and constraints. Trends Plant Sci 21:1000-1007 
Pavela R, Morshedloo MR, Mumivand H, Khorsand GJ, Karami A, Maggi F et al (2020) Phenolic monoterpene-rich essential oils from Apiaceae and Lamiaceae species: insecticidal activity and safety evaluation on non-target earthworms. Entoml Gen 40:421-435

Pérez-Hedo M, Urbaneja A (2016) The Zoophytophagous Predator Nesidiocoris tenuis: A Successful but Controversial Biocontrol Agent in Tomato Crops. Advances in Insect Control and Resistance Management. Springer International Publishing, Cham, pp 121-138

Pérez-Hedo M, Bouagga S, Jaques JA, Flors V, Urbaneja A (2015) Tomato plant responses to feeding behavior of three zoo- phytophagous predators (Hemiptera: Miridae). Biol Control 86:46-51

Pérez-Hedo M, Riahi C, Urbaneja A (2021a) Use of zoophytophagous mirid bugs in horticultural crops: current challenges and future perspectives. Pest Manag Sci 77:33-42

Pérez-Hedo M, Gallego C, Roda A, Kostyk B, Triana M, Alférez F et al (2021b) Biological traits of the predatory mirid Macrolo- phus praeclarus, a candidate biocontrol agent for the Neotropical region. Bull Entomol Res. https://doi.org/10.1017/S000748532 1000067

Picanço M, Leite GLD, Guedes RNC, Silva EA (1998) Yield loss in trellised tomato affected by insecticidal sprays and plant spacing. Crop Prot 17:447-452

Picanço MC, Bacci L, Queiroz RB, Silva GA (2011) Social wasp predators of Tuta absoluta. Sociobiology 58:1-13

Piri A, Sahebzadeh N, Zibaee A, Sendi JJ, Shamakhi L, Shahriari M (2020) Toxicity and physiological effects of ajwain (Carum copticum, Apiaceae) essential oil and its major constituents against Tuta absoluta (Meyrick) (Lepidoptera: Gelechiidae). Chemosphere 256:127103

Ponti L, Gutierrez AP, Campos MR, Desneux N, Biondi A, Neteler M (2021) Biological invasion risk assessment of Tuta absoluta: mechanistic versus correlative methods. Biol Invas. https://doi. org/10.1007/s10530-021-02613-5

Puigmarri M, Bosch MP, Guerrero A (2015) An improved and convenient new synthesis of the pheromone components of the tomato leafminer Tuta absoluta. Synthesis (germany) 47:961-968

Qu YY, Chen X, Monticelli LS, Zhang F, Desneux N, Dai HJ et al (2020) Parasitism performance of the parasitoid Trichogramma dendrolimi on the plum fruit moth Grapholitha funebrana. Entomol Gen 40:385395

Ragsdale DW, Landis DA, Brodeur J, Heimpel GE, Desneux N (2011) Ecology and management of the soybean aphid in North America. Annu Rev Entomol 56:375-399

Reyes M, Rocha K, Alarcon L, Siegwart M, Sauphanor B (2012) Metabolic mechanisms involved in the resistance of field populations of Tuta absoluta (Meyrick) (Lepidoptera: Gelechiidae) to spino- sad. Pestic Biochem Physiol 102:45-50

Rezaei N, Karimi J, Hosseini M, Goldani M, Campos-Herrera R (2015) Pathogenicity of two species of entomopathogenic nematodes against the greenhouse whitefly, Trialeurodes vaporariorum (Hemiptera: Aleyrodidae), in laboratory and greenhouse experiments. J Nematol 47:60-66

Rizk AM (2016) Effectiveness of different bio-techniques for controlling the pin worm, Tuta absoluta (Meyrick) (Lepidoptera: Gelechiidae). Egypt J Biol Pest Cont 26:797-802

Roda AL, Brambila J, Barria J, Euceda X, Korytkowski C (2015) Efficiency of trapping systems for detecting Tuta absoluta (lepidoptera: Gelechiidae). J Econ Entomol 108:2648-2654

Roda A, Castillo J, Allen C, Urbaneja A, Pérez-Hedo M, Weihman S et al (2020) Biological control potential and drawbacks of three zoophytophagous mirid predators against Bemisia tabaci in the United States. Insects. https://doi.org/10.3390/insects11100670

Roditakis E, Skarmoutsou C, Staurakaki M (2013) Toxicity of insecticides to populations of tomato borer 
Tuta absoluta (Meyrick) from Greece. Pest Manag Sci 69:834-840

Roditakis E, Vasakis E, Grispou M, Stavrakaki M, Nauen R, Gravouil M et al (2015) First report of Tuta absoluta resistance to diamide insecticides. J Pest Sci 88:9-16

Roditakis E, Mavridis K, Riga M, Vasakis E, Morou E, Rison JL et al (2017a) Identification and detection of indoxacarb resistance mutations in the para sodium channel of the tomato leafminer, Tuta absoluta. Pest Manag Sci 73:1679-1688

Roditakis E, Steinbach D, Moritz G, Vasakis E, Stavrakaki M, llias A et al (2017b) Ryanodine receptor point mutations confer diamide insecticide resistance in tomato leafminer, Tuta absoluta (Lepidoptera: Gelechiidae). Insect Biochem Mol Biol 80:11-20

Roditakis E, Vasakis E, Garria-Vidal L, Martfnez-AguirreRison MDRJL, Odile M et al (2018) A four-year survey on insecticide resistance and likelihood of chemical control failure for tomato leaf miner Tuta absoluta in the European/Asian region. J Pest Sci 91:421-435

Rostami E, Madadi H, Abbasipour H, Allahyari H, Cuthbertson AGS (2020) Pest density influences on tomato pigment contents: The South American tomato pinworm scenario. Entomol Gen 40:195-205

Rwomushana I, Beale T, Chipabika G, Day R, Gonzalez-Moreno P, Lamontagne-Godwin J et al (2019) Evidence Note. Tomato leafminer (Tuta absoluta): impacts and coping strategies for Africa. CABI Working Paper 12. https://doi.org/10.1079/CABIC OMM-62-8100

Salas Gervassio NG, Luna MG, Lee S, Salvo A, Sanchez NE (2016) Trophic web associated with the South American tomato moth Tuta absoluta: implications for its conservation biological control in Argentina. Agric for Entomol 18:137-144

Salas Gervassio NG, Aquino D, Vallina C, Biondi A, Luna MG (2019a) A re-examination of Tuta absoluta parasitoids in South America for optimized biological control. J Pest Sci 92:1343-1357

Salas Gervassio NG, Luna MG, Minardi GM, Sanchez NE (2019b) Assessing inoculative releases of Pseudapanteles dignus (Hymenoptera: Braconidae) for the biological control of Tuta absoluta (Lepidoptera: Gelechiidae). Crop Prot 124:104830

Salas Gervassio NG (2017) Perspectivas del uso del endoparasitoide nativo Pseudapanteles dignus (Muesebeck) (Hymenoptera: Braconidae) para el control biologico de la polilla del tomateTuta absoluta (Meyrick) (Lepidoptera: Gelechiidae). Evaluacion a campo". PhD Dissertation, Universidad Nacional de La Plata, Argentina.

Sanchez NE, Pereyra PC, Luna MG (2009) Spatial patterns of parasitism of the solitary parasitoid Pseudapanteles dignus (Hymenoptera: Braconidae) on Tuta absoluta (Lepidoptera: Gelechiidae). Environ Entomol 38:365-374

Santoiemma G, Tonina L, Marini L, Duso C, Mori N (2020) Integrated management of Drosophila suzukii in sweet cherry orchards. Entomol Gen 40:297-305

Schnepf E, Crickmore N, Van-Rie J, Lereclus D, Baum J, Feitelson J et al (1998) Bacillus thuringiensis and Its Pesticidal Crystal Proteins. Microbiol Mol Biol Rev 62:775-806

Selale H, Dagli F, Mutlu N, Doganlar S, Frary A (2017) Cry1Ac- mediated resistance to tomato leaf miner (Tuta absoluta) in tomato. Plant Cell Tiss Organ Cult 131:65-73

Sellami S, Cherif M, Abdelkefi-Mesrati L, Tounsi S, Jamoussi K (2014) Toxicity, activation Process, and histopathological effect of Bacillus thuringiensis vegetative insecticidal protein Vip3Aa16 on Tuta absoluta. 2014. Appl Biochem Biotechnol 175:1992-1999

Shah FM, Razaq M, Ali Q, Ali A, Shad SA, Aslam M, Hardy ICW (2020) Action threshold development in cabbage pest management using synthetic and botanical insecticides. Entomol Gen 40:157-172

Shaltiel-Harpaz L, Gerling D, Graph S, Kedoshim H, Azolay L, Rozenberg T et al (2016) Control of the 
tomato leafminer, Tuta absoluta (Lepidoptera: Gelechiidae), inopen-field tomatoes by indigenous natural enemies occurring in Israel. J Econ Entomol 109:120-131

Silva GA, Picanço MC, Bacci L, Crespo ALB, Rosado JF, Guedes RNC (2011) Control failure likelihood and spatial dependence of insecticide resistance in the tomato pinworm, Tuta absoluta. Pest Manag Sci 67:913-920

Silva WM, Berger M, Bass C, Balbino VQ, Amaral MHP, Campos AM et al (2015) Status of pyrethroid resistance and mechanisms in Brazilian populations of Tuta absoluta. Pestic Bio- chem Physiol 122:8-14

Silva TBM, Silva WM, Campos MR, Silva JE, Ribeiro LMS, Siqueira HAA (2016) Susceptibility levels of Tuta absoluta (Meyrick) (Lepidoptera: Gelechiidae) to minor classes of insecticides in Brazil. Crop Prot 79:80-86

Silva SS (2008) Fatores da biologiareprodutiva que influenciam o manejocomportamental de Tuta absoluta (Meyrick) (Lepidoptera: Gelechiidae). MS thesis: Universidade Federal Rurasl de Pernambuco Brasil

Simberloff D, Martin J-L, Genovesi P, Maris V, Wardle DA, Aronson J et al (2013) Impacts of biological invasions: what's what and the way forward. Trends Ecol Evol 28:58-66

Siqueira HAA, Guedes RNC, Picanço MC (2000a) Insecticide resistance in populations of Tuta absoluta (Lepidoptera: Gelechiidae). Agric for Entomol 2:147-153

Siqueira HAA, Guedes RNC, Picanco MC (2000b) Cartap resistance and synergism in populations of Tuta absoluta (Lep., Gelechiidae). J Appl Entomol 124:233-238

Siqueira HAA, Guedes RNC, Fragoso DB, Magalhaes LC (2001) Abamectin resistance and synergism in Brazilian populations of Tuta absoluta (Meyrick) (Lepidoptera: Gelechiidae). Int J Pest Manag 47:247251

Snoeren TAL, Sitbon E, Levy D (2017) Resistance to arthropod pest in tomatoes. United States Patent Application Publication, USA Soares MA, Campos MR, Passos LC, Carvalho GA, Haro MM, Lavoir AV et al (2019) Botanical insecticide and natural enemies: a potential combination for pest management against Tuta absoluta. J Pest Sci 92:1433-1443

Svatos A, Attygalle AB, Jham GN, Frighetto RTS, Vilela EF, Saman D et al (1996) Sex pheromone of tomato pest Scrobipalpuloides absoluta (lepidoptera: Gelechiidae). J Chem Ecol 22:787-800

Sylla S, Brévault T, Diarra K, Bearez P, Desneux N (2016) Life-history traits of Macrolophus pygmaeus with different prey foods. PLoS ONE 11:e0166610

Sylla S, Brévault T, Monticelli LS, Diarra K, Desneux N (2019) Geographic variation of host preference by the invasive tomato leaf miner Tuta absoluta: implications for host range expansion. J Pest Sci 92:1387-1396

Tait G, Mermer S, Stockton D, Jana L, Avosani S et al (2021) Drosophila suzukii (Diptera: Drosophilidae): a decade of research towards a sustainable integrated pest management program. $J$ Pest Sci. https://doi.org/10.1093/jee/toab158

Tall S, Meyling NV (2018) Probiotics for plants? Growth promotion by the entomopathogenic fungus beaeria bassiana depends on nutrient availability. Microb Ecol 7:1002-1008

Tezze AA, Botto EN (2004) Effect of cold storage on the quality of Trichogramma nerudai (Hymenoptera: Trichogrammatidae). Biol Control 30:11-16

Theoduloz C, Vega A, Salazar M, Gonzalez E, Meza-Basso L (2003) Expression of a Bacillus thuringiensis $d$-endotoxin cry1Ab gene in Bacillus subtilis and Bacillus licheniformis strains that naturally colonize the phylloplane of tomato plants (Lycopersicon esculentum, Mills). J Appl Microbiol 94:375-381

Thomine E, Jeavons E, Rusch A, Bearez P, Desneux N (2020) Effect of crop diversity on predation 
activity and population dynamics of the mirid predator Nesidiocoris tenuis. J Pest Sci 93:1255-1265

Turkoz S, Kaskavalci G (2016) Determination of the efficacy of some entomopathogenic nematodes against Tuta absoluta (Meyrick) (Lepidoptera: Gelechiidae) under laboratory conditions. Türk Entomol Derg 40:175-183

Uchôa-Fernandes MA, Vilela EF (1994) Field trapping of the tomato worm Scrobipalpula absoluta (Meyrick) (Lep., Gelechiidae). Ann Soc Entomol Bras 23:271-277

Urbaneja A, Monton H, Molla O (2009) Suitability of the tomato borer Tuta absoluta as prey for Macrolophus pygmaeus and Nesidi- ocoris tenuis. J Appl Entomol 133:292-296

Urbaneja A, Gonzalez-Cabrera J, Arno J, Gabarra R (2012) Prospects for the biological control of Tuta absoluta in tomatoes of the Mediterranean basin. Pest Manag Sci 68:1215-1222

Urbaneja A, Desneux N, Gabarra $R$ et al (2013) Biology, ecology and management of the south american tomato pinworm, Tuta absoluta. In: Pena JE (ed) Potential Invasive Pests of Agricultural Crops. CABI Invasives Series, Oxfordshire, pp 98-125

Urbaneja-Bernat P, Bru P, Gonzalez-Cabrera J, Urbaneja A, Tena A (2018) Reduced phytophagy in sugar provisioned mirids. J Pest Sci 92:1139-1148

Vacas S, Alfaro C, Primo J, Navarro-Llopis V (2011) Studies on the development of a mating disruption system to control the tomato leafminer, Tuta absoluta Povolny (Lep-idoptera: Gelechiidae). Pest Manag Sci 67:1473-1480

Vacas S, Lopez J, Primo J, Navarro-Llopis V (2013) Response of Tuta absoluta (Lepidoptera: Gelechiidae) to different pheromone emission levels in greenhouse tomato crops. Environ Entomol 42:1061-1068

Van Damme VM, Beck BK, Berckmoes E, Moerkens R, Wittemans L, De Vis R et al (2016) Efficacy of entomopathogenic nematodes against larvae of Tuta absoluta in the laboratory. Pest Manag Sci 72:17021709

Van Veen FJ, Morris RJ, Godfray HCJ (2006) Apparent competition, quantitative food webs, and the structure of phytophagous insect communities. Annu Rev Entomol 51:187-208

Varshney R, Ballal CR (2017) Studies on evaluation of Nesidiocoris tenuis (Reuter) (Hemiptera: Miridae) preying on invasive insect pest Tuta absoluta (Meyrick) (Lepidoptera: Gelechiidae) and its damage to tomato plant. J Biol Control 31:69-73

Vega FE (2018) The use of fungal entomopathogens as endophytes in biological control: a review. Mycologiam 110:4-30

Verheggen F, Fontus RB (2019) First record of Tuta absoluta in Haiti. Entomol Gen 38:349-353

Vickers J, Cory JS, Entwistle PF (1991) DNA characterization of eight geographic isolates of granulosis virus from the potato tuber moth (Phthorimaea operculella) (Lepidoptera: Gelechiidae). J Invertebr Pathol 57:334-342

Virgala MB, Botto EN (2010) Biological studies on Trichogramma- toidea bactrae Nagaraja (Hymenoptera: Trichogrammatidae), egg parasitoid of Tuta absoluta Meyrick (Lepidoptera: Gelechiidae). Neotrop Entomol 39:612-617

Wang MH, Ismoilov K, Li H, Zhang X, Lu ZZ, Feng LK et al (2021) Polygyny of Tuta absoluta may affect sex pheromone-based control techniques. Entomol Gen 41:357-367

Witzgall P, Stelinski L, Gut L, Thomson D (2008) Codling moth management and chemical ecology. Annu Rev Entomol 53:503-522

Witzgall P, Kirsch P, Cork A (2010) Sex pheromones and their impact on pest management. J Chem 


\section{Ecol 36:80-100}

Zang LS, Wang S, Zhang F, Desenux N (2021) Biological control with Trichogramma in China: history, present status and perspectives. Annu Rev Entomol 66:463-484

Zappalà L, Siscaro G, Biondi A, Molla O, Gonzâlez-Cabrera J, Urbaneja A (2012) Efficacy of sulphur on Tuta absoluta and its side effects on the predator Nesidiocoris tenuis. J Appl Entomol 136:401-409

Zappalà L, Biondi A, Alma A, Al-Jboory IJ, Arno J, Bayram A et al (2013) Natural enemies of the South American moth, Tuta abso- luta, in Europe, North Africa and Middle East, and their potential use in pest control strategies. J Pest Sci 86:635-647

Zhang J, Khan SA, Hasse C, Ruf S, Heckel DG, Bock R (2015) Full crop protection from an insect pest by expression of long double stranded RNAs in plastids. Science 347:911-914

Zhang J, Khan SA, Heckel DG, Bock R (2017) Next generation insect resistant plants: RNAi-mediated crop protection. Trends Biotech- nol 8:871-882

Zibaee I, Mahmood K, Esmaeily M, Bandani AR, Kristensen M (2018) Organophosphate and pyrethroid resistances in the tomato leaf miner Tuta absoluta (Lepidoptera: Gelechiidae) from Iran. $J$ Appl Entomol 142:181-191

Zouba A, Mahjoubi K (2010) Biological control of Tuta absoluta (Lepidoptera: Gelechiidae) with release of Trichogramma cacoeciae (Hymenoptera: Trichogrammatidae) in tomato greenhouses in Tunisia. African J Plant Sci Biotech 4:85-87

Zouba A, Chermiti B, Chraiet R, Mahjoubi K (2013) Effect of two indigenous Trichogramma species on the infestation level by tomato miner Tuta absoluta in tomato greenhouses in the SouthWest of Tunisia. Tunis J Plant Prot 8:87-106 